\title{
Cellobiose dehydrogenase modified electrodes: advances by materials science and biochemical engineering
}

\author{
Roland Ludwig • Roberto Ortiz • Christopher Schulz • \\ Wolfgang Harreither • Christoph Sygmund • Lo Gorton
}

Received: 28 September 2012 /Revised: 27 November 2012 / Accepted: 3 December 2012 / Published online: 18 January 2013

(C) The Author(s) 2013. This article is published with open access at Springerlink.com

\begin{abstract}
The flavocytochrome cellobiose dehydrogenase $(\mathrm{CDH})$ is a versatile biorecognition element capable of detecting carbohydrates as well as quinones and catecholamines. In addition, it can be used as an anode biocatalyst for enzymatic biofuel cells to power miniaturised sensor-transmitter systems. Various electrode materials and designs have been tested in the past decade to utilize and enhance the direct electron transfer (DET) from the enzyme to the electrode. Additionally, mediated electron transfer (MET) approaches via soluble redox mediators and redox polymers have been pursued. Biosensors for cellobiose, lactose and glucose determination are based on $\mathrm{CDH}$ from different fungal producers, which show differences with respect to substrate specificity, $\mathrm{pH}$ optima, DET efficiency and surface binding affinity. Biosensors for the detection of quinones and catecholamines can use carbohydrates for analyte regeneration and signal amplification. This review discusses different approaches to enhance the sensitivity and selectivity of CDH-based biosensors, which focus on (1) more efficient DET on chemically modified or nanostructured electrodes, (2) the synthesis of custom-made redox polymers for higher MET currents and (3) the engineering of enzymes and reaction
\end{abstract}

Published in the topical collection Bioelectroanalysis with guest editors Nicolas Plumeré, Magdalena Gebala and Wolfgang

Schuhmann.

R. Ludwig $\cdot$ W. Harreither $\cdot$ C. Sygmund

Food Biotechnology Laboratory, Department of Food Sciences and Technology, BOKU-University of Natural Resources and Life Sciences, Vienna, Muthgasse 18,

1190 Vienna, Austria

R. Ortiz $\cdot$ C. Schulz $\cdot$ L. Gorton $(\bowtie)$

Department of Analytical Chemistry/Biochemistry and Structural

Biology, Lund University, P.O. Box 124, 22646 Lund, Sweden

e-mail: Lo.Gorton@biochemistry.lu.se pathways. Combination of these strategies will enable the design of sensitive and selective CDH-based biosensors with reduced electrode size for the detection of analytes in continuous on-site and point-of-care applications.

Keywords Biosensors · Carbohydrates · Catecholamines · Cellobiose dehydrogenase $\cdot$ Electron transfer $\cdot$ Nanomaterials

$\begin{array}{ll}\text { Abbreviations } \\ \text { AuNP } & \text { gold nanoparticles } \\ \text { BQ } & \text { p-benzoquinone } \\ \text { BOx } & \text { bilirubin oxidase } \\ \text { CBM1 } & \text { carbohydrate binding module (family 1) } \\ \text { CDH } & \text { cellobiose dehydrogenase } \\ \text { CNP } & \text { carbon nanoparticles } \\ \text { CNT } & \text { carbon nanotube } \\ \text { CV } & \text { cyclic voltammetry, cyclic voltammogram } \\ \text { cyt } c & \text { cytochrome } c \text { (from horse heart) } \\ \text { CYT } & \text { cytochrome domain of CDH } \\ \text { DCIP } & \text { 2,6-dichloroindophenol } \\ \text { DET } & \text { direct electron transfer } \\ \text { DH } & \text { flavodehydrogenase domain of CDH } \\ E^{\circ \prime} & \text { formal potential } \\ \text { ET } & \text { electron transfer } \\ \text { GA } & \text { glutaraldehyde } \\ \text { IET } & \text { intramolecular electron transfer } \\ \text { LbL } & \text { layer by layer } \\ \text { MET } & \text { mediated electron transfer } \\ \text { MUA } & \text { mercapto-1-undecanoic acid } \\ \text { MUOH } & \text { mercapto-1-undecanol } \\ \text { MWCNT } & \text { multi-walled carbon nanotubes } \\ \text { NHE } & \text { normal hydrogen electrode } \\ \text { Os-EDP } & \text { osmium electrodeposition paint } \\ \text { PBS } & \text { phosphate buffered saline } \\ & \end{array}$


PEGDGE polyethyleneglycol diglycidyl ether

PMO polysaccharide monooxygenase

SAM self-assembled monolayer

SiNP silica nanoparticles

SPR surface plasmon resonance

SWCNT single-walled carbon nanotube

\section{Introduction}

The last few years have witnessed tremendous development in bioelectrochemistry largely owing to the increased knowledge of making nanostructured electrodes surfaces [1-4] in combination with the understanding of how to bring about controlled architectures/orientation of biomolecules on such surfaces [5-10] and also the closer collaboration between (bio)electrochemists and biochemists/molecular biologists [11-22]. Additionally, research on and the foreseen need for practical applications, e.g. in electrochemical biosensors [23], biofuel cells [24-26] and bioelectrosynthesis [27], have also speeded up the research activities in this area. The drive to make bioelectrochemical devices/systems as simple as possible has put a focus on how to bring about efficient electron transfer reactions between the biologically derived material and electrodes without the need for additional and possibly leaching (and toxic) chemicals [28-32].

Cellobiose dehydrogenase $(\mathrm{CDH})$ is a flavocytochrome [33] belonging to the restricted number of oxidoreductases that in their native wild-type form show efficient direct electron transfer (DET) between the active site and an electrode surface. CDH does this because it consists of two separate domains with different structures and inherent properties joined together by a polypeptide linker region. The larger flavodehydrogenase domain $\left(\mathrm{DH}_{\mathrm{CDH}}\right)$ is catalytically active, whereas the smaller cytochrome domain $\left(\mathrm{CYT}_{\mathrm{CDH}}\right)$ contains haem $b$ as a cofactor and acts as an electron transfer protein between $\mathrm{DH}_{\mathrm{CDH}}$ and a terminal, macromolecular electron acceptor. By 1991 Hill and co-workers [34] had divided the oxidoreductases, from a bioelectrochemical point of view, into two different groups-intrinsic and extrinsic - and characterised them as follows [34]:

Catalytic reaction between an enzyme and its substrate takes place within a highly localised assembly of redox-active sites. There need be no electron transfer pathways from these sites to the surface of the enzyme, where, it is presumed, it would interact with an electrode. For such intrinsic redox enzymes, electrode reactions may require (1) that the sites of the catalytic reaction be close to the protein surface, (2) that the enzyme can deform without loss of activity, (3) that the electrode surface projects into the enzyme, (4) that electron pathways be introduced by modification of the enzyme. With the extrinsic redox enzymes, there is usually another protein involved in transporting electrons and therefore an electron transfer pathway exists within the enzyme connecting the active sites to an area on the surface where the ancillary protein binds. If this area could be disposed toward an electrode, it would be possible for the enzyme electrochemistry to be obtained.

From a structural point of view $\mathrm{CDH}[35,36]$ is obviously an extrinsic redox enzyme, where the $\mathrm{CYT}_{\mathrm{CDH}}$ acts as a built-in mediator [37]. What further supports this is that in several recent reports it has been shown that copperdependent polysaccharide monooxygenase (PMO) is likely to be the physiological redox partner of $\mathrm{CDH}$ which can therefore explain the role of $\mathrm{CYT}_{\mathrm{CDH}}$ (Fig. 1) [38-41].

In 2010 we reviewed the basic electrochemical properties of CDH [19]; however, since then, a series of investigations on the biochemistry and bioelectrochemistry of various CDHs [42-44] have been pursued as well as one on the fundamentals of the intramolecular electron transfer (IET) between the two domains of $\mathrm{CDH}$ [45]. Furthermore a series of genetic work has been done to improve the glucoseoxidising properties of CDH (Ortiz et al. submitted) [46], in particular, as well as nanostructuring of both carbon [47] and gold-based electrodes [48, 49] to improve the loading and orientation of $\mathrm{CDH}$ on the electrode surface and thus also current densities. Especially in the field of biofuel cells [49-51] great progress has been made on the spatial arrangement of $\mathrm{CDH}$ on electrodes (Ortiz et al. submitted) [47-49, 52, 53] and CDH-based biosensors [54-58]. Such progress has prompted this new review on the bioelectrochemistry of $\mathrm{CDH}$. One should also note that $\mathrm{CDH}$ has been used to make gold nanoparticles (AuNPs) and with the use of scanning electrochemical microscopy it was possible also to localise such AuNPs on surfaces with the help of CDH [59].

\section{Occurrence and classification of CDH}

Cellobiose dehydrogenase is secreted by white- and brownrot, phytopathogenic as well as composting fungi from the dikaryotic phyla Basidiomycota and Ascomycota under cellulolytic culture conditions [60]. The CDH enzyme family is a heterogenous group of proteins with protein sequences between 749 and 816 amino acids long and sequence identities as low as $35 \%$. Phylogenetic analyses of these sequences showed several well-supported branches. Basidiomycete $\mathrm{CDH}$ sequences (from the Atheliales, Corticiales and Polyporales) form the branch of class I CDHs. Class II consists only of sequences of ascomycete origin (Sordariales, Xylariales and Hypocreales). This class of $\mathrm{CDHs}$ partitions into two subclasses: class IIA CDHs and class IIB CDHs. For members of the Eurotiales, Helotiales and Pleosporales, $\mathrm{CDH}$-encoding sequences of a separate phylogenetic branch were found in sequenced genomes. The secretion of these 


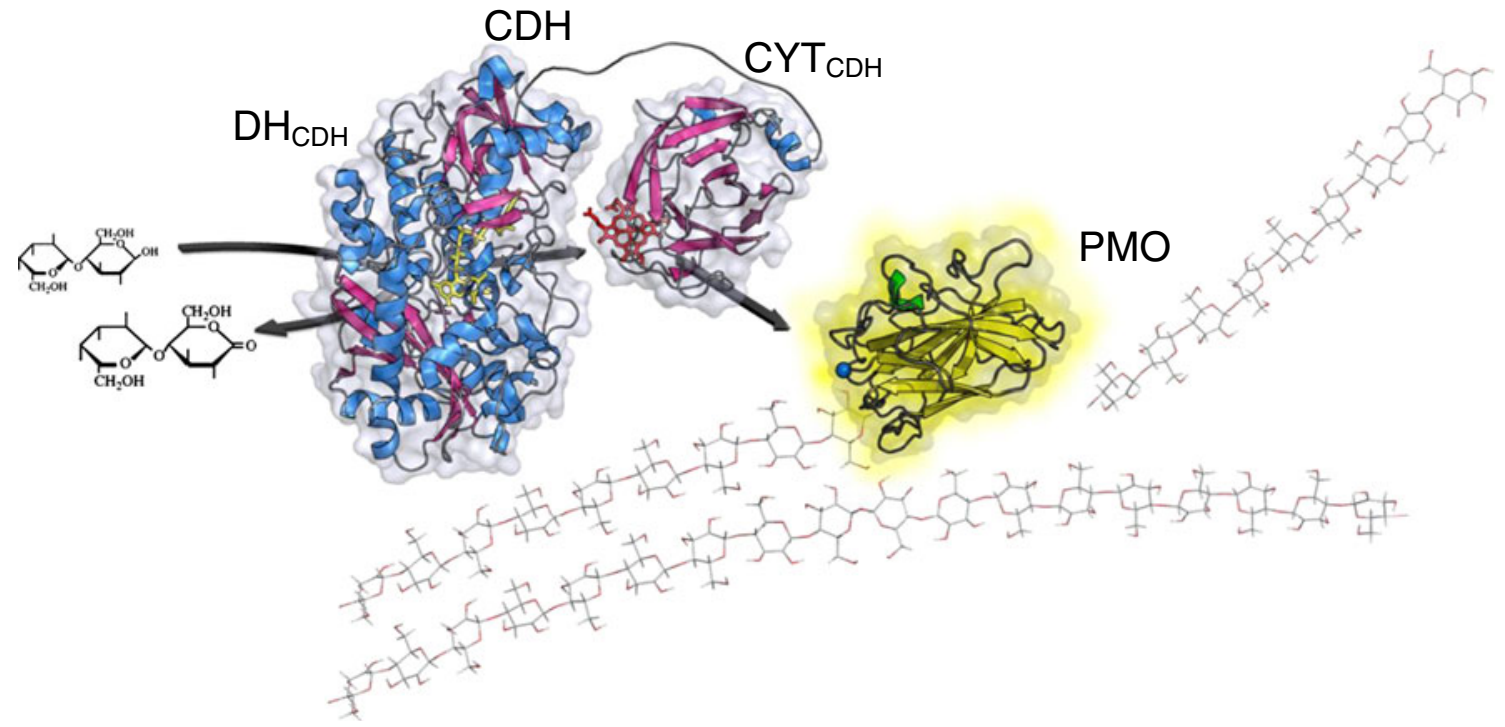

Fig. 1 Proposed in vivo function of $\mathrm{CDH}$. Electrons from the oxidation of cellobiose or higher cellodextrins are acquired by $\mathrm{CDH}$, which donates them to the surface-exposed type-2 copper

class III CDHs has not yet been confirmed [42, 60, 61]. The molecular architecture of CDHs from class I and II are slightly different. Whereas class I CDHs have supposedly a carbohydrate binding site on the $\mathrm{DH}_{\mathrm{CDH}}$, class IIA CDHs carry a small C-terminal family 1 carbohydrate binding module (CBM1), which is missing in class IIB CDHs.

The widespread appearance of $\mathrm{CDH}$ in fungi and the fact that it constitutes a considerable fraction of the lignocellulolytic enzymes secreted by these fungi $(0.5-12 \%)$ implies that $\mathrm{CDH}$ has an important function in wood degradation [62]. Recently the composition of lignocellulolytic enzyme cocktails and the up- and downregulation of single constituents were studied using transcriptomic and proteomic analyses [63-66]. Results from studies on the well-known ascomycete fungus Neurospora crassa and on the whiterot basidiomycete model organism Phanerochaete chrysosporium revealed that $\mathrm{CDH}$ genes are up-regulated during growth under cellulolytic conditions [66-68]. Important fungal producers of $\mathrm{CDH}$ are summarised in Table 1.

\section{Structure and function}

$\mathrm{CDH}$ is an extracellular fungal flavocytochrome (cellobiose:acceptor 1-oxidoreductase, EC 1.1.99.18) and is a monomeric protein consisting of two domains connected by a flexible linker of about 20 amino acids. The molecular mass ranges from 85 up to $101 \mathrm{kDa}$ depending on the degree of glycosylation, which can account for up to $16 \%$ of the molecular mass $[19,42,69,70]$. The $\mathrm{DH}_{\mathrm{CDH}}$ is a member of the glucose-methanol-choline oxidoreductase (GMC) family [61, 71]. The available centre of PMO to activate molecular oxygen for the cleavage of cellulose [38-41]. Initial studies show that the electron transfer via the $\mathrm{CYT}_{\mathrm{CDH}}$ is quite efficient [62]

structure of $P$. chrysosporium $\mathrm{DH}_{\mathrm{CDH}}$ (PDB identifiers $1 \mathrm{KDG}$ and 1NNA [36]) is peanut shaped with dimensions of $72 \times 57 \times 45 \AA$. The average molecular mass of $\mathrm{DH}_{\mathrm{CDH}}$ is $\sim 60 \mathrm{kDa}$ without glycosylation, which can contribute up to $\sim 10 \%$ of the total mass. The isoelectric point of $\mathrm{DH}_{\mathrm{CDH}}$ is low and varies for different enzymes but is usually around $5[60,72,73]$. Oxidation of carbohydrates is catalysed by the non-covalently bound FAD cofactor in $\mathrm{DH}_{\mathrm{CDH}}$. The $\mathrm{CYT}_{\mathrm{CDH}}$ structure available from P. chrysosporium (PDB identifiers 1D7B and 1D7C [35]) is formed by two ellipsoidal antiparallel $\beta$-sheets with dimensions of $47 \times$ $36 \times 47 \AA$. The average molecular mass is $\sim 22 \mathrm{kDa}$ without glycosylation and the isoelectric point of the $\mathrm{CYT}_{\mathrm{CDH}}$ is very low, around 3. The haem cofactor is coordinated by Met 65 and His 163. This unusual ligation of haem $b$ in $\mathrm{CYT}_{\mathrm{CDH}}$ causes a relatively low redox potential, which is about 100 $160 \mathrm{mV}$ vs. normal hydrogen electrode (NHE) at $\mathrm{pH} 7.0[62$, $74,75]$. The N-terminal $\mathrm{CYT}_{\mathrm{CDH}}$ is connected to $\mathrm{DH}_{\mathrm{CDH}}$ via a flexible linker, which keeps the two domains in close contact and allows IET between them. Hence CDH can transfer reducing equivalents from an electron donor (e.g. cellobiose) via its two redox centres to different types of electron acceptors. Reoxidation of $\mathrm{CDH}$ can occur either directly at the (reduced) $\mathrm{DH}_{\mathrm{CDH}}$ domain by transfer of reduction equivalents to a two-electron acceptor (e.g. quinones) or, alternatively, electrons can be sequentially shuttled from the reduced FAD to the haem $b$ cofactor, followed by consecutive reduction of two one-electron acceptors (ferric iron complexes, cytochrome $c)[60,72,73]$.

Recently a novel electron acceptor for $\mathrm{CDH}$ was identified. The PMOs are copper-dependent carbohydrate active enzymes (CAZy) of family GH61, which can receive 
Table 1 Production of CDH by fungi

\begin{tabular}{|c|c|c|c|c|}
\hline Fungal producer of $\mathrm{CDH}$ & Phylum & Volumetric activity $\left(\mathrm{U} \mathrm{L}^{-1}\right)$ & Activity assay $^{\mathrm{c}}$ & Reference \\
\hline Phanerochaete chrysosporium & $\mathrm{B}$ & $66\left(600^{\mathrm{a}}\right)$ & Cellobiose, cyt $c, \mathrm{pH} 4.5$ & {$[139,140]$} \\
\hline Pycnoporus cinnabarinus & $\mathrm{B}$ & 355 & Cellobiose, DCIP, pH 4.5 & {$[141]$} \\
\hline Sclerotium rolfsii & $\mathrm{B}$ & $7400\left(15000^{\mathrm{b}}\right)$ & Lactose, cyt $c, \mathrm{pH} 4.5$ & {$[69,142]$} \\
\hline Trametes villosa & $\mathrm{B}$ & 580 & Lactose, cyt $c, \mathrm{pH} 3.5$ & {$[142]$} \\
\hline Trametes versicolor & $\mathrm{B}$ & 2030 & Cellobiose, cyt $c$, pH 3.5 & {$[143]$} \\
\hline Ceriporiopsis subvermispora & $\mathrm{B}$ & 170 & Lactose, DCIP, pH 6.0 & {$[70]$} \\
\hline Thielavia heterothallica & A & 47 & Cellobiose, cyt $c$, pH 4.5 & {$[144,145]$} \\
\hline Corynascus thermophilus & $\mathrm{A}$ & 4000 & Lactose, DCIP, pH 5.0 & {$[42]$} \\
\hline Neurospora crassa & A & 100 & Lactose, DCIP, pH 5.5 & {$[42]$} \\
\hline Chaetomium sp. INBI 2-26(-) & $\mathrm{A}$ & 190 & Cellobiose, DCIP, pH 6.5 & {$[146]$} \\
\hline
\end{tabular}

$A$ ascomycete, $B$ basidiomycete, DCIP 2,6-dichloroindophenol

${ }^{a}$ When supplemented with bovine calf serum

${ }^{\mathrm{b}}$ When using increased concentrations of peptone or certain amino acids

${ }^{\mathrm{c}}$ Activities can vary when using different assays based on other carbohydrate substrates (electron donors) and electron acceptors. The $\mathrm{pH}$ used in the assay is identical or close to the $\mathrm{pH}$ optimum

reducing equivalents from $\mathrm{CDH}$ and subsequently cleave cellulose by an oxidative mechanism. This interaction could be the key for the elucidation of the biological function of $\mathrm{CDH}$ and might end decades of speculation (Fig. 1) [38-41].

\section{Catalytic properties of $\mathrm{CDH}$}

Preferred substrates of all CDHs are the $\beta$-1,4-linked diand oligosaccharide breakdown products of cellulosecellobiose or cellodextrins. Lactose has a very similar structure and is, although certainly not a natural substrate, also readily converted by $\mathrm{CDHs}$ [60]. A slight difference is observed between class I CDHs, which strongly discriminate glucose turnover, whereas some class II CDHs can also oxidise other mono- and disaccharides although with lower catalytic efficiencies. This difference might be an adaption to different fungal habitats and substrates [42, 45]. Catalysis takes place in the active site of $\mathrm{DH}_{\mathrm{CDH}}$, where two electrons and two protons are subtracted from the anomeric carbon atom of a substrate sugar residue in the reductive cycle, which results in a fully reduced FAD [76]. In the oxidative cycle the $\mathrm{FADH}_{2}$ in the $\mathrm{DH}_{\mathrm{CDH}}$ reduces electron acceptors such as 2,6-dichloroindophenol (DCIP), $o$ - or $p$-benzoquinone and their derivatives, the 2,2'azino-bis(3-ethylbenzothiazoline-6-sulfonate) (ABTS) cation radical, triiodide, strongly complexed iron ions, or oxygen. Alternatively, electrons can be donated to the haem $b$. Some electron acceptors like weakly complexed iron ions, cyt $c$, PMO and electrode surfaces depend on the action of the $\mathrm{CYT}_{\mathrm{CDH}}$. Cyt $c$ is one of only a few one-electron acceptors which solely act with $\mathrm{CYT}_{\mathrm{CDH}}$ and therefore is a good tool to estimate the IET (Fig. 2). The pH plays an important role in this reaction cascade. In class I CDHs the catalytic reaction at the active site and IET work only under acidic $\mathrm{pH}$ conditions. In class II CDHs three different groups of $\mathrm{CDH}$ with different IET behaviours were distinguished according to their $\mathrm{pH}$-dependent interaction with cyt $c$ : acidic, intermediate or neutral/alkaline IET optima [42] (Fig. 3). The same IET behaviour was found for these $\mathrm{CDHs}$ on polarised graphite electrodes [45].

\section{Recombinant production of CDH}

Although many lignocellulose-degrading fungi produce $\mathrm{CDH}$ in reasonable amounts their cultivation and subsequent protein purification are difficult and time consuming. Therefore, several $c d h$ genes have been cloned and

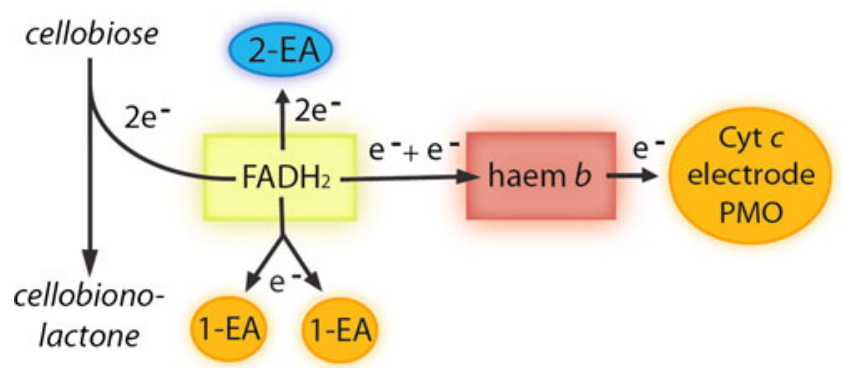

Fig. 2 Electron transfer in $\mathrm{CDH}$ from the substrate to various terminal electron acceptors. One- and two-electron acceptors (EA) can be reduced directly by the $\mathrm{FADH}_{2}$ in the $\mathrm{DH}_{\mathrm{CDH}}$. Alternatively, electrons can be transferred by IET to the haem $b$ in the $\mathrm{CYT}_{\mathrm{CDH}}$, which works as a relay for the reduction of macromolocular electron acceptors like $\mathrm{PMO}$, cyt $c$ or an electrode 
Fig. 3 Comparison of $\mathrm{pH}$ profiles of basidiomycetous class I and ascomycetous class II CDHs. In the left column acidic class I CDH from Ceriporiopsis subvermispora $(\mathrm{Cs} \mathrm{CDH})$ is shown above $\mathrm{CDH}$ from Trametes villosa (TvCDH) and Phanerochaete chrysosporium (PcCDH). The right column shows class II CDHs from Myriococcum thermophilum (MtCDH),

Hypoxylon haematostroma (HhCDH) and Corynascus thermophilus $(\mathrm{Ct} \mathrm{CDH})$ with intermediate and neutral $\mathrm{pH}$ optima. DCIP (grey lines) indicates the activity of $\mathrm{DH}_{\mathrm{CDH}}$, whereas cyt $c$ (black lines) is used to determine the $\mathrm{pH}$ dependency of the IET. For further information, see $[42,43,45]$

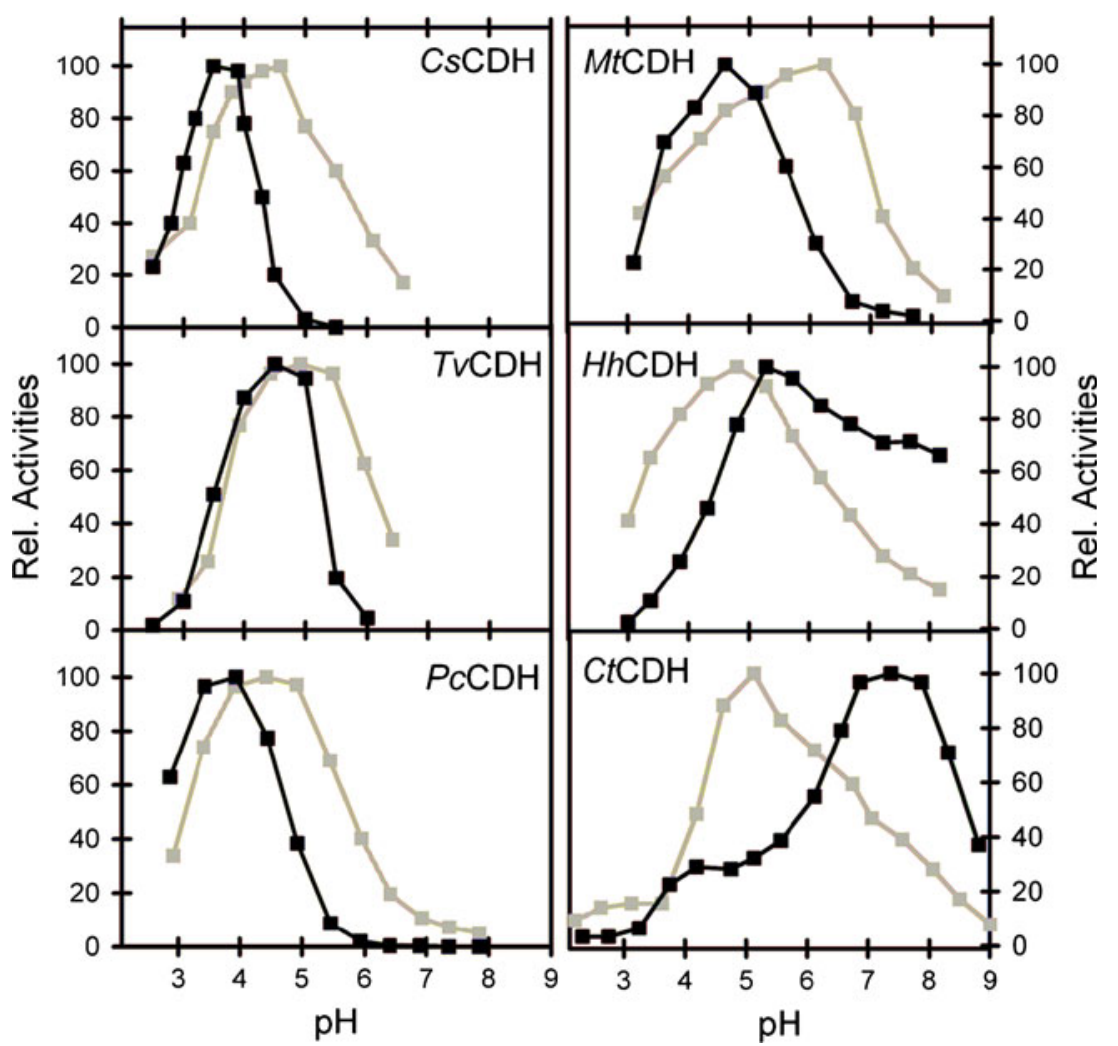

expressed in recombinant expression hosts. Li et al. [77] were the first to report recombinant expression of $\mathrm{CDH}$ by homologous overexpression of $\mathrm{CDH}$ in P. chrysosporium. The expression level was rather low $\left(600 \mathrm{U} \mathrm{L}^{-1}\right)$, cultivation time was long (9 days) and genetic manipulation was difficult and time consuming. Therefore, Yoshida et al. [78] established the methylotrophic yeast Pichia pastoris as a heterologous expression system for P. chrysosporium $\mathrm{CDH}$. Owing to the high reported expression levels, easy genetic manipulation and the ability of Pichia to perform eukaryotic post-translational modifications, it was used as an expression host for several basidiomyceteous and ascomeceteous $\mathrm{CDHs}$ during the following years (Table 2). Additionally, two ascomeceteous CDHs from Thielavia terrestris and Humicola insolens were recombinantly expressed in a fungal system, viz. Aspergillus oryzae [79, 80]. Several attempts to express $\mathrm{CDH}$ in the bacterial expression system Escherichia coli failed because of the different posttranslational modifications of the two domains. However, the expression of the $\mathrm{DH}_{\mathrm{CDH}}$ of $P$. chrysosporium was recently reported [81].

The advantages of recombinant protein expression are a fast, reliable and efficient enzyme production and the possibility to generate genetically engineered enzymes. However, some drawbacks have to be considered. A substoichiometric occupation of the catalytic sites with the cofactor FAD in $C$. thermophilus $\mathrm{CDH}$ results in a generally lower specific activity of CDHs expressed in P. pastoris [75]. The fact that Pichia and Aspergillus produce several glycoforms of the recombinant protein results in an inhomogeneous enzyme preparation in respect to molecular mass and degree of glycosylation. Depending on the cultivation conditions and employed media a varying amount of proteolytically cleaved $\mathrm{DH}_{\mathrm{CDH}}$ appears during purification $[75,82]$.

\section{Direct electron transfer}

The electron transfer pathways between the $\mathrm{DH}_{\mathrm{CDH}}$ and an electrode can occur in principle along three different routes as illustrated in Figs. 2 and 4. In the first reaction the sugar substrate, an aldose, is oxidised at the $\mathrm{C} 1$ position (only the $\beta$-anomer is a substrate for $\mathrm{CDH}$ ) into its corresponding lactone and concurrently the FAD in the active site of the $\mathrm{DH}_{\mathrm{CDH}}$ is fully reduced to $\mathrm{FADH}_{2}-\mathrm{DH}_{\mathrm{CDH}}$, reaction (1):

aldose $+\mathrm{FAD}-\mathrm{DH}_{\mathrm{CDH}} \rightarrow$ lactone $+\mathrm{FADH}_{2}-\mathrm{DH}_{\mathrm{CDH}}$

The reoxidation of $\mathrm{FADH}_{2}-\mathrm{DH}_{\mathrm{CDH}}$ can be accomplished by a $2 \mathrm{e}^{-}, 2 \mathrm{H}^{+}$acceptor such as quinone (Q) or an equivalent aromatic redox compound according to reaction (2):

$\mathrm{FADH}_{2}-\mathrm{DH}_{\mathrm{CDH}}+\mathrm{Q} \rightarrow \mathrm{FAD}-\mathrm{DH}_{\mathrm{CDH}}+\mathrm{QH}_{2}$ 
Table 2 Recombinant production of $\mathrm{CDH}$ and $\mathrm{DH}_{\mathrm{CDH}}$ by recombinant expression hosts

\begin{tabular}{|c|c|c|c|c|}
\hline Fungal producer of $\mathrm{CDH}$ & Expression host & Volumetric activity $\left(\mathrm{U} \mathrm{L}^{-1}\right)$ & Activity assay & Reference \\
\hline Phanerochaete chrysosporium & P. chrysospor. $^{\mathrm{a}}$ & 600 & Cellobiose, cyt $c, \mathrm{pH} 4.5$ & {$[77]$} \\
\hline Phanerochaete chrysosporium & P. pastoris & 1800 & Cellobiose, cyt $c, \mathrm{pH} 4.5$ & {$[78]$} \\
\hline P. chrysosporium $\mathrm{DH}_{\mathrm{CDH}}$ & E. coli & $733^{\mathrm{b}}$ & Cellobiose, DCIP, pH 5.0 & {$[81]$} \\
\hline Pycnoporus cinnabarinus & P. pastoris & 7800 & Cellobiose, DCIP, pH 5.0 & {$[147]$} \\
\hline Trametes versicolor & P. pastoris & 5218 & Cellobiose, cyt $c, \mathrm{pH} 4.2$ & {$[148]$} \\
\hline Myriococcum thermophilum & P. pastoris & 2150 & Lactose, DCIP, pH 5.0 & {$[82]$} \\
\hline Neurospora crassa (CDH IIA) & P. pastoris & 1700 & Lactose, DCIP, pH 5.0 & {$[62]$} \\
\hline Neurospora crassa (CDH IIB) & P. pastoris & 410 & Lactose, DCIP, pH 5.0 & {$[62]$} \\
\hline Corynascus thermophilus & P. pastoris & 376 & Lactose, DCIP, pH 5.5 & {$[75]$} \\
\hline Thielavia terrestris & A. oryzae & NG & Cellobiose, DCIP, pH 6.0 & [79] \\
\hline Humicola insolens & A. oryzae & NG & Cellobiose, DCIP, pH 7.0 & {$[80]$} \\
\hline
\end{tabular}

$N G$ data not given

${ }^{a}$ Homologous overexpression

${ }^{\mathrm{b}}$ Value refers to cell-free extract after cell disruption and not to cultivation volume

The reduced quinone, $\mathrm{QH}_{2}$, will be reoxidised at the electrode if the applied potential $\left(E_{\text {app }}\right)$ is set higher than the formal potential of the $\mathrm{Q} / \mathrm{QH}_{2}$ redox couple, $\mathrm{E}_{\mathrm{Q} / \mathrm{QH}_{2}}^{\mathrm{O} \text {, }}$, reaction (3):

$\mathrm{QH}_{2} \stackrel{E_{\mathrm{app}}>\mathrm{E}_{\mathrm{Q} / \mathrm{OH}}^{\mathrm{O}} \longrightarrow}{\longrightarrow} \mathrm{Q}+2 \mathrm{H}^{+}+2 \mathrm{e}^{-}$

Alternatively, a $1 \mathrm{e}^{-}$, non- $\mathrm{H}^{+}$acceptor, e.g. an $\mathrm{Os}^{3+}$ complex $\left(\mathrm{Os}^{3+}\right)$, accepts the electrons sequentially from the $\mathrm{FADH}_{2}-\mathrm{DH}_{\mathrm{CDH}}$, whereby $\mathrm{Os}^{2+}$ complex $\left(\mathrm{Os}^{2+}\right)$ and the enzyme-stabilised semiquinone of the bound FAD, $\mathrm{FADH} \cdot{ }^{-} \mathrm{DH}_{\mathrm{CDH}}$, are formed in reaction (4):

$\mathrm{FADH}_{2}-\mathrm{DH}_{\mathrm{CDH}}+\mathrm{Os}^{3+} \rightarrow \mathrm{FADH} \cdot{ }^{-} \mathrm{DH}_{\mathrm{CDH}}+\mathrm{Os}^{2+}+\mathrm{H}^{+}$

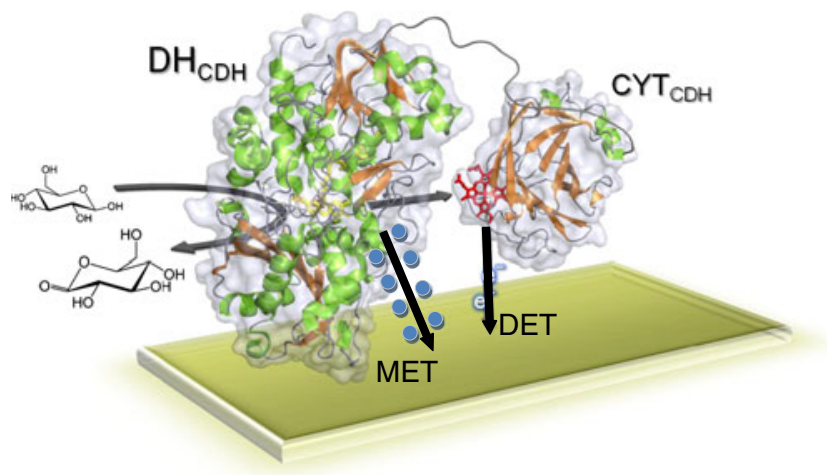

Fig. 4 Electron transfer between both $\mathrm{CDH}$ domains and the terminal electron acceptor. DET depends on $\mathrm{CYT}_{\mathrm{CDH}}$ as an electron shuttle, whereas MET (blue spheres indicate soluble mediators or polymeric redox centres) transfers electrons directly from $\mathrm{DH}_{\mathrm{CDH}}$ to the electrode surface
This reaction is then followed by the second electron transfer to a second $\mathrm{Os}^{3+}$, whereby the fully oxidised $\mathrm{DH}_{\mathrm{CDH}}$ is regained, reaction (5):

$\mathrm{FADH} \cdot{ }^{-} \mathrm{DH}_{\mathrm{CDH}}+\mathrm{Os}^{3+} \rightarrow \mathrm{FAD}-\mathrm{DH}_{\mathrm{CDH}}+\mathrm{Os}^{2+}+\mathrm{H}^{+}$

The two $\mathrm{Os}^{2+}$ formed will be reoxidised at the electrode if $E_{\text {app }}$ is set higher than the formal potential of the $\mathrm{Os}^{3+/ 2+}$ redox couple, $\mathrm{E}_{\mathrm{Os}^{3+/ 2+}}^{\mathrm{O}}$, reaction (6):

$2 \mathrm{Os}^{2+} \stackrel{E_{\text {app }}>\mathrm{E}_{0 \mathrm{~s}^{3+1 / 2+}}^{\circ+}}{\longrightarrow} 2 \mathrm{Os}^{3+}+2 \mathrm{e}^{-}$

The electrons can also be transferred from $\mathrm{FADH}_{2}-\mathrm{DH}_{\mathrm{CDH}}$ to the $\mathrm{Fe}^{3+}-\mathrm{CYT}_{\mathrm{CDH}}$ sequentially in an IET process according to reaction (7):

$$
\begin{gathered}
\mathrm{FADH}_{2}-\mathrm{DH}_{\mathrm{CDH}}-\mathrm{Fe}^{3+}-\mathrm{CYT}_{\mathrm{CDH}} \stackrel{\mathrm{IET}}{\longrightarrow} \mathrm{FADH} \bullet{ }^{-} \mathrm{DH}_{\mathrm{CDH}} \\
-\mathrm{Fe}^{2+}-\mathrm{CYT}_{\mathrm{CDH}}+\mathrm{H}^{+}
\end{gathered}
$$

This first electron transfer step is followed by reoxidation of the reduced $\mathrm{CYT}_{\mathrm{CDH}}, \mathrm{Fe}^{2+}-\mathrm{CYT}_{\mathrm{CDH}}$, by an $\mathrm{e}^{-}$ acceptor such as $\mathrm{Os}^{3+}$ or cytochrome $c$ (or by the electrode, see below); however, the second electron from the $\mathrm{DH}_{\mathrm{CDH}}$ will then be subsequently transferred to the $\mathrm{CYT}_{\mathrm{CDH}}$, reaction (8):

$$
\begin{aligned}
& \mathrm{FADH} \bullet{ }^{-} \mathrm{DH}_{\mathrm{CDH}}-\mathrm{Fe}^{2+}-\mathrm{CYT}_{\mathrm{CDH}}+\mathrm{Os}^{3+} \\
& \rightarrow \mathrm{FAD}-\mathrm{DH}_{\mathrm{CDH}}-\mathrm{Fe}^{2+}-\mathrm{CYT}_{\mathrm{CDH}}+\mathrm{Os}^{2+}
\end{aligned}
$$


Finally the last electron will be transferred from the $\mathrm{CYT}_{\mathrm{CDH}}$ to a second $1 \mathrm{e}^{-}$acceptor molecule, reaction (9):

$$
\begin{aligned}
& \mathrm{FAD}-\mathrm{DH}_{\mathrm{CDH}}-\mathrm{Fe}^{2+}-\mathrm{CYT}_{\mathrm{CDH}}+\mathrm{Os}^{3+} \\
& \rightarrow \mathrm{FAD}-\mathrm{DH}_{\mathrm{CDH}}-\mathrm{Fe}^{3+}-\mathrm{CYT}_{\mathrm{CDH}}+\mathrm{Os}^{2+}
\end{aligned}
$$

When CDH is immobilised on the electrode surface and in the absence of any competing $\mathrm{e}^{-}$acceptors, the reoxidation of the reduced enzyme can be summarised as follows, reaction (10):

$$
\begin{gathered}
\mathrm{FADH}_{2}-\mathrm{DH}_{\mathrm{CDH}}-\mathrm{Fe}^{3+}-\mathrm{CYT}_{\mathrm{CDH}} \stackrel{1 \mathrm{st} \text { IET step }}{\longrightarrow} \mathrm{FADH} \cdot{ }^{-} \mathrm{DH}_{\mathrm{CDH}} \\
-\mathrm{Fe}^{2+}-\mathrm{CYT}_{\mathrm{CDH}}+\mathrm{H}^{+}
\end{gathered}
$$

This step is followed by a first electron transfer (ET) step to the electrode, which is immediately followed by a second IET step delivering the second electron from the $\mathrm{DH}_{\mathrm{CDH}}$ to the $\mathrm{CYT}_{\mathrm{CDH}}$, reaction (11):

$$
\begin{aligned}
& \mathrm{FADH} \cdot-\mathrm{DH}_{\mathrm{CDH}} \\
& -\mathrm{Fe}^{2+}-\mathrm{CYT}_{\mathrm{CDH}} \stackrel{\text { 1st ET to electrode and 2nd IET step }}{\longrightarrow} \mathrm{FAD} \\
& -\mathrm{DH}_{\mathrm{CDH}}-\mathrm{Fe}^{2+}-\mathrm{CYT}_{\mathrm{CDH}}+\mathrm{H}^{+}+\mathrm{e}^{-}(\text {electrode })
\end{aligned}
$$

Finally the second electron is then delivered to the electrode, reaction (12):

$$
\begin{aligned}
& \mathrm{FAD}-\mathrm{DH}_{\mathrm{CDH}} \\
& -\mathrm{Fe}^{2+}-\mathrm{CYT}_{\mathrm{CDH}} \stackrel{\text { 2nd ET to electrode }}{\longrightarrow} \mathrm{FAD}-\mathrm{DH}_{\mathrm{CDH}} \\
& -\mathrm{Fe}^{3+}-\mathrm{CYT}_{\mathrm{CDH}}+\mathrm{e}^{-} \text {(electrode) }
\end{aligned}
$$

It is basically the DET properties of $\mathrm{CDH}$ that form the basis for the bioelectrochemical interest in this redox enzyme, ever since it was first documented [83]. The rather strict selectivity of the originally investigated class I basidiomycete $\mathrm{CDHs}$ for cellodextrins and lactose [60, 84] mainly found application in lactose biosensors for the dairy industry [55, 58, 85] or cellobiose biosensors that can be used to follow cellulose hydrolysis caused by cellulose-hydrolysing enzymes [54, 86]. However, when it was realised that the recently discovered ascomycete $\mathrm{CDHs}$ (class IIA and IIB) could also have high turnover rates for glucose (and a series of other mono- and oligosaccharides) and especially at neutral $\mathrm{pH}$ values (in contrast to class I CDHs that work best under slightly acidic conditions) an increased interest in $\mathrm{CDH}$ for application in biosensors and biofuel cells appeared [30, 42, 44, 49-51, 56, 57, 87-92].

\section{Optimisation of direct electron transfer}

Two approaches are used to optimise DET currents from $\mathrm{CDH}$ to electrodes. The first approach is based on new electrode materials, nanostructures and chemically modified electrode surfaces to either enhance the effective surface area available for $\mathrm{CDH}$ binding, or to increase the DET rate by suitable orientation of the enzyme on the surface. The second, biochemical approach uses modifications of the enzyme or the reaction cascade to increase the current of $\mathrm{CDH}$-based electrodes. The following sections investigate the published work in the area of direct $\mathrm{CDH} /$ electrode interaction.

Novel nanostructures

The desire to increase the current density of bioelectrodes based on DET has led to the construction and use of nanostructured architectures so that a higher loading of the redox enzyme and a higher probability of correct orientation for DET can be obtained. Both the use of nanostructures based on the drop-casting deposition technique of nanomaterials such as single-walled carbon nanotubes (SWCNTs) [47, 89-91] (Ortiz et al. submitted) [93] or gold nanoparticles (AuNPs) $[48,49,51]$ onto the electrode surface of $\mathrm{Au}$, glassy carbon or graphite electrodes, as well as prefabricated carbon nanotube (CNT)-modified screen-printed electrodes [55, 57, 58] has been used and in all instances the use of nanomaterials resulted in an improved current density. An overview of the nanostructured materials used is presented in Table 3. For all the nanomaterials and immobilisation techniques tested only bioelectrocatalysis from $\mathrm{CYT}_{\mathrm{CDH}}$ was observed.

\section{Carbon-based nanomaterials}

Initial investigations with various CDHs on SWCNT- or MWCNT-modified electrodes were based on direct adsorption of $\mathrm{CDH}$ on the nanomodified surface $[55,57,89,90$, 93]. These studies used oxidatively shortened SWCNTs, kept as a suspension in water, without previous modification or commercially available screen-printed electrodes with MWCNT or SWCNT. No previous or further functionalisation of the nanomaterial was done and only in some of the studies was a cross-linker, i.e. polyethyleneglycol diglycidyl ether (PEGDGE) or glutaraldehyde (GA), was used in a following step to stabilise the enzyme-nanoparticle layer on the electrode surface. For screen-printed electrodes the use of a cross-linker increased the electrocatalytical currents in the presence of substrate by one order of magnitude for $T$. villosa and Phanerochaete sordida CDH-modified MWCNT screen-printed electrodes possibly owing to dissolution of certain components in the paste, thereby exposing a higher surface area for electric communication with the 


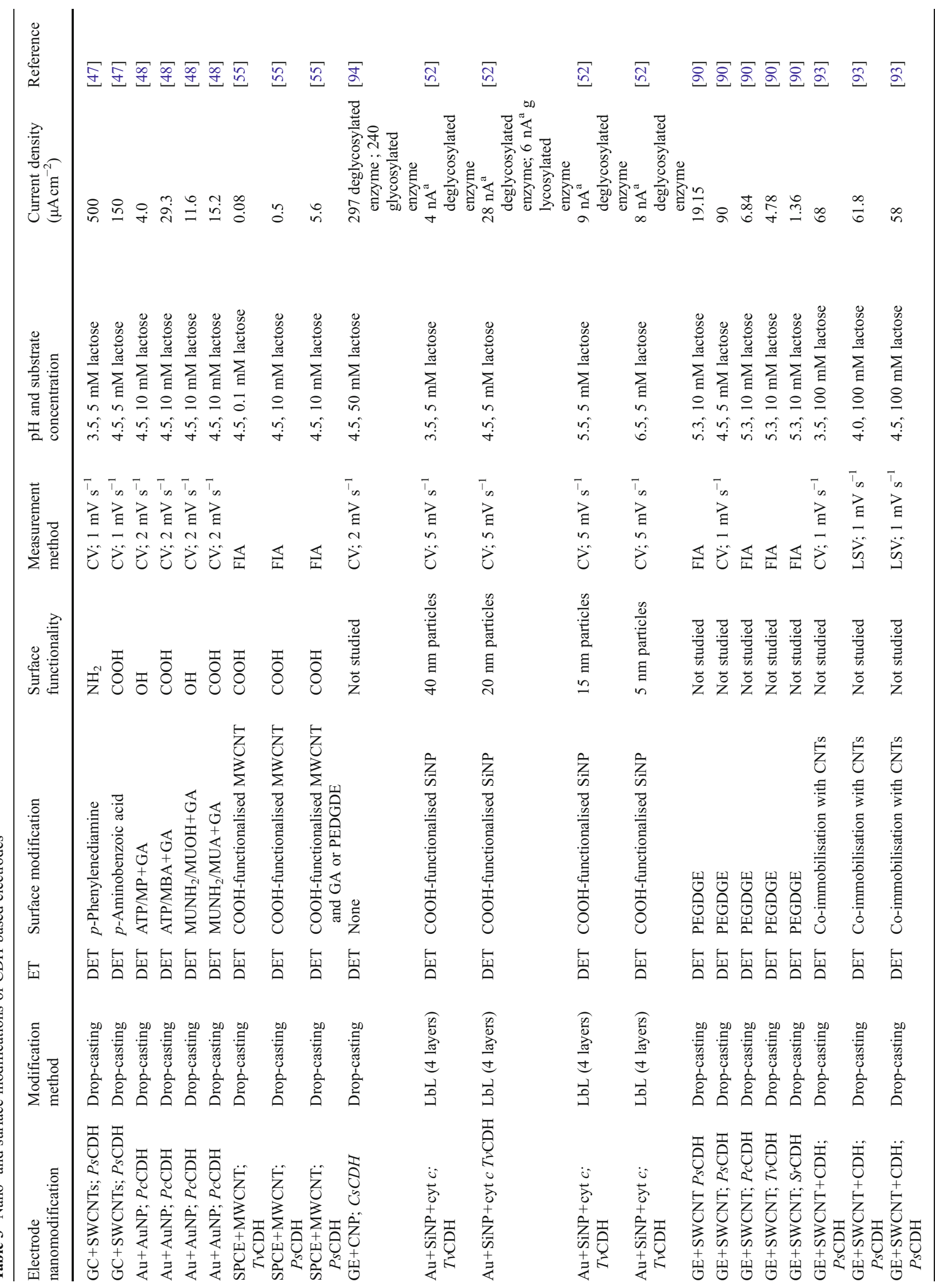




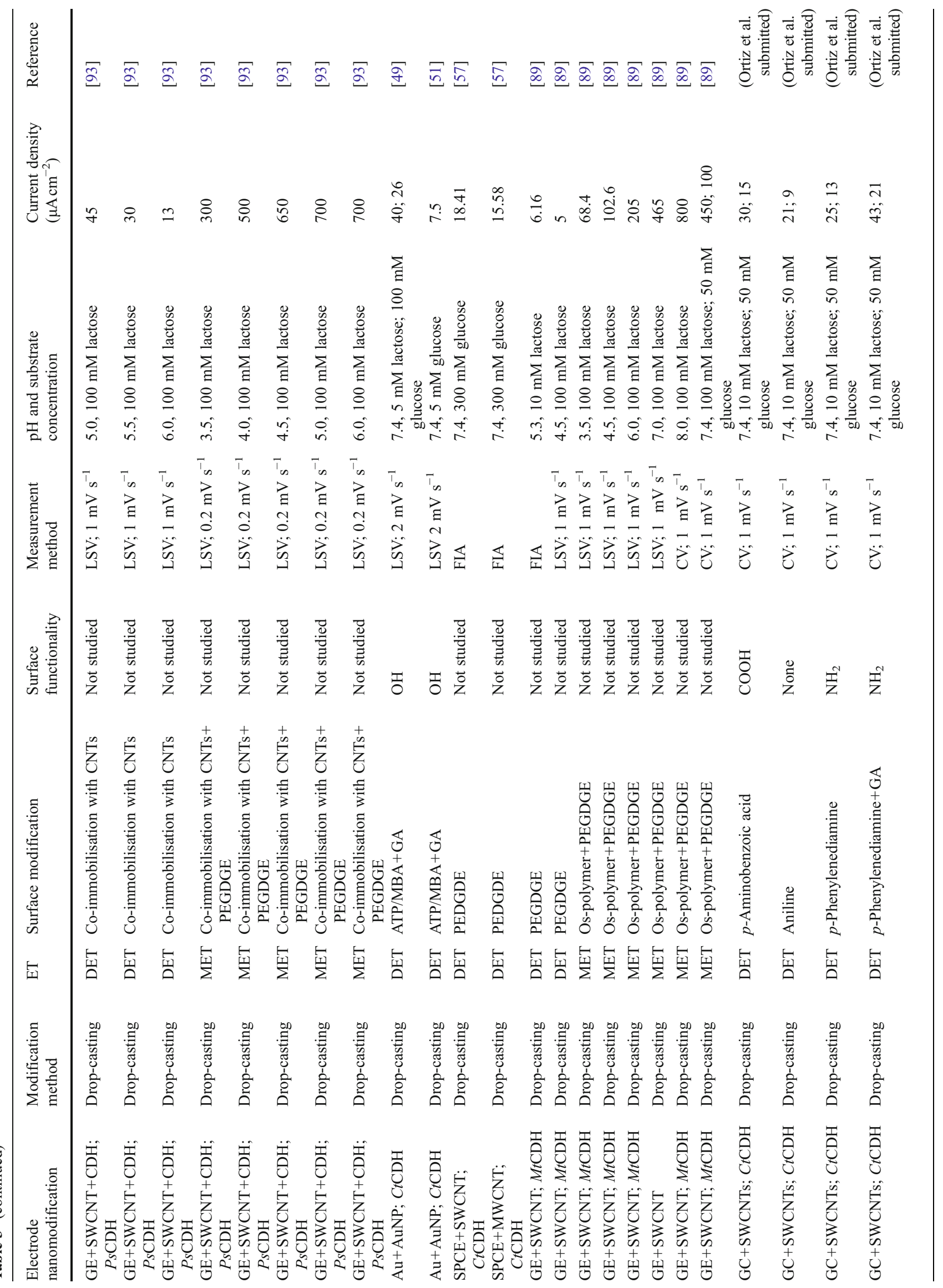


immobilised CDH [55]. In the scope of this type of nonfurther functionalisation of the carbon nanomaterial, Ortiz et al. [94] increased the specific surface area by drop-casting carbon nanoparticles (CNPs) with a diameter of $27 \mathrm{~nm}$ onto graphite electrodes, which increased the electrocatalytical current by 350 times for deglycosylated Ceriporiopsis subvermispora $\mathrm{CDH}\left(297 \mu \mathrm{A} \mathrm{cm}^{-2}\right)$ and more than 500 times for glycosylated C. subvermispora CDH $\left(240 \mu \mathrm{A} \mathrm{cm}^{-2}\right)$, see Table 3.

Gold nanoparticles and nanomaterials

Drop-casting of citrate-stabilised AuNPs with a diameter of $19 \mathrm{~nm}$ onto the surface of Au disk electrodes [95] was used in combination with mixed self-assembled thiol monolayers (SAMs), onto which P. chrysosporium CDH [48] or $C$. thermophilus $\mathrm{CDH}[49,51]$ was covalently attached. The mixed SAM featured different thiols with amino, carboxy or hydroxyl head groups. The bifunctional cross-linker GA was used to form covalent bonds between the amino-terminated thiols and lysine residues on the enzyme. Cyclic voltammetry (CV) showed clear redox waves in the absence of substrate for all mixed SAMs tested and the heterogeneous electron transfer constant, $k_{\mathrm{s}}$, could be calculated. An enhancement of the electrocatalytical activity of $P$. chrysosporium $\mathrm{CDH}$ of up to 75 times was achieved by this technique [48]. The procedure has been used further to prepare glucose $/ \mathrm{O}_{2}$ biofuel cell anodes using $C$. thermophilus $\mathrm{CDH}$ as the bioelement, in combination with cathodes based on adsorbed bilirubin oxidase (BOx) on AuNP-modified Au disks and nanowires $[49,51]$ (Table 3).

Layer-by-layer nanostructures

A different approach to achieve higher currents was taken by Lisdat et al., who, on the basis of previous work combining cyt $c$ modified electrodes with $\mathrm{CDH}$ [96] and other redox enzymes [97-100], constructed a supramolecular structure using a layer-by-layer (LbL) immobilisation technique combining alternate layers of silica nanoparticles (SiNPs) and a mixture of $T v \mathrm{CDH}$ and cyt $c$ (Fig. 5) [52]. Various numbers of layers, i.e. 1, 2, 3 and 4, were investigated using both native glycosylated and also deglycosylated $T v \mathrm{CDH}$; the deglycosylated $\mathrm{CDH}$ yielded higher currents. The optimal SiNP particle size was $20 \mathrm{~nm}$ [52]. An LbL assembly technique was used. First a mixed SAM of MUA/MUOH was used to coat the Au surface and then SiNPs were adsorbed on the partially negatively charged surface, and finally a mixture containing $T \nu \mathrm{CDH}$ and cyt $c$ was added and the nanostructure was built up to four layers [52]. The same type of alkanethiol mixture was used to adsorb cyt $c$ on a SAM of MUOH/MUA on gold wires. The bioelectrochemistry in the presence and the absence of 
Fig. 5 Schematic

representation of a supramolecular $[\mathrm{SiNP} / \mathrm{CDH}$. cyt $c$ ] architecture prepared on a cyt $c$ monolayer electrode (M). The cyt $c$ monolayer is assembled on a mixed thiol layer (MUOH/MUA). The layer by layer structure is [SiNPs/CDH . cyt $c]_{\mathrm{n}}(n=1,2,3,4)$, where $n$ indicates the number of layers of $\mathrm{SiNPs} / \mathrm{CDH} \cdot$ cyt $c$. Reproduced from [52] with permission from The American Chemical Society

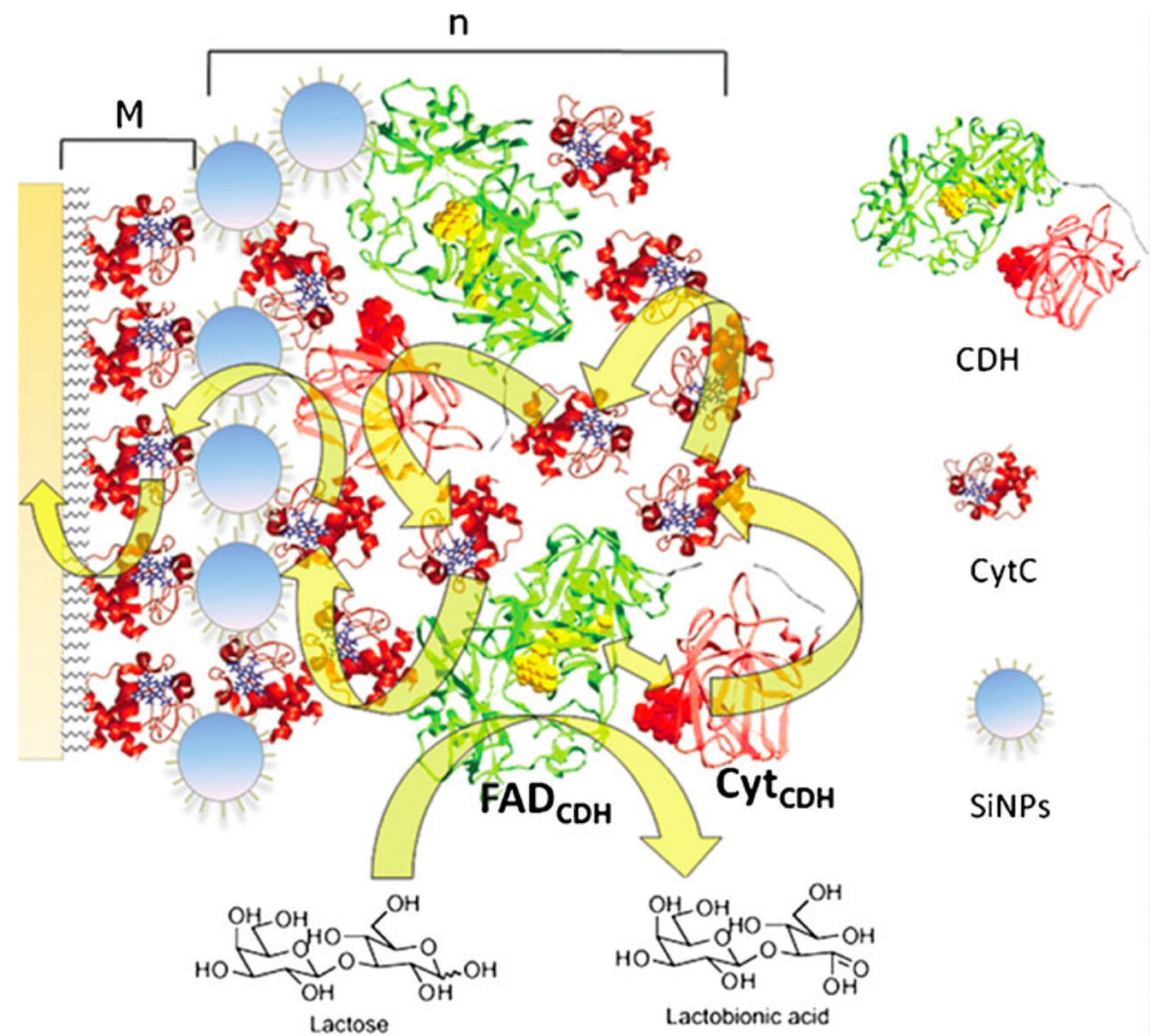

substrate was studied for solutions of $T v \mathrm{CDH}$ and $C t \mathrm{CDH}$ using this cyt $c$ electrode; significantly, a shift of the optimal $\mathrm{pH}$ for electrocatalysis of cellobiose was observed using this approach [53].

\section{Derivatisation of electrode surfaces}

In the last few years functionalised SWCNTs have been tested in combination with $\mathrm{CDH}$. It is established that the charge of the surface where $\mathrm{CDH}$ is immobilised has a strong effect on the electrochemistry of CDH. Investigations on different SAMs showed a strong effect of the functional group of the used thiol on the efficiency of the electrochemistry of $\mathrm{CDH}$ [44, 101-104]. Using the aryl amines $p$-phenylenediamine $\left(\mathrm{NH}_{2}-\mathrm{PD}\right)$ or $p$-aminobenzoic acid $(\mathrm{COOH}-$ PD) for diazonium activation of the electrode surface, Tasca et al. [47] introduced amino or carboxylic groups, respectively, onto the SWCNTs previously drop-cast on glassy carbon electrodes. In the final step Phanerochaete sordida $\mathrm{CDH}$, belonging to the class I CDHs, was adsorbed onto the modified electrode, where the positively charged $-\mathrm{NH}_{2}$ functionalised surface or the negatively charged $-\mathrm{COOH}$ functionalised surface at the actual $\mathrm{pH}$ was used during $\mathrm{CV}$ measurements. For the $-\mathrm{NH}_{2}$ functionalised surface a current density of $500 \mu \mathrm{A} \mathrm{cm} \mathrm{cm}^{-2}$ was obtained in the presence of $5 \mathrm{mM}$ lactose, which is the highest current density observed for any $\mathrm{CDH}$-modified electrode based on DET (Fig. 6). For the $-\mathrm{COOH}$ functionalised SWCNTs a current density of $\sim 150 \mu \mathrm{A} \mathrm{cm} \mathrm{cm}^{-2}$ was obtained. The increased current density of the $-\mathrm{NH}_{2}$ modified surface was attributed to a better orientation of the mainly negatively charged $P$. sordida $\mathrm{CDH}$ (isoelectric point=5.7) on the electrode. A similar modification procedure using a larger range of diazonium salts on SWCNTs drop-cast on GC was performed by (Ortiz et al. submitted), but in this case using the class II C. thermophilus $\mathrm{CDH}$, which gave current densities of up to $25 \mu \mathrm{A} \mathrm{cm} \mathrm{cm}^{-2}$ in the presence of $50 \mathrm{mM}$ glucose.

\section{Thiol-modified gold electrodes}

Reports on facile electrochemistry of CDH trapped between a gold electrode modified with a thiol-based SAM and covered with a permselective membrane have appeared since the beginning of the 1990s [87, 101-104]. When such electrodes were investigated by $\mathrm{CV}$ they revealed clear nonturnover DET between the haem $b$ cofactor of the $\mathrm{CYT}_{\mathrm{CDH}}$ in the absence of substrate, whereas in the presence of substrate a clear catalytic current was observed. The interaction between $\mathrm{CDH}$ and the thiol-based SAM-modified electrode results in facile electrochemistry which is 

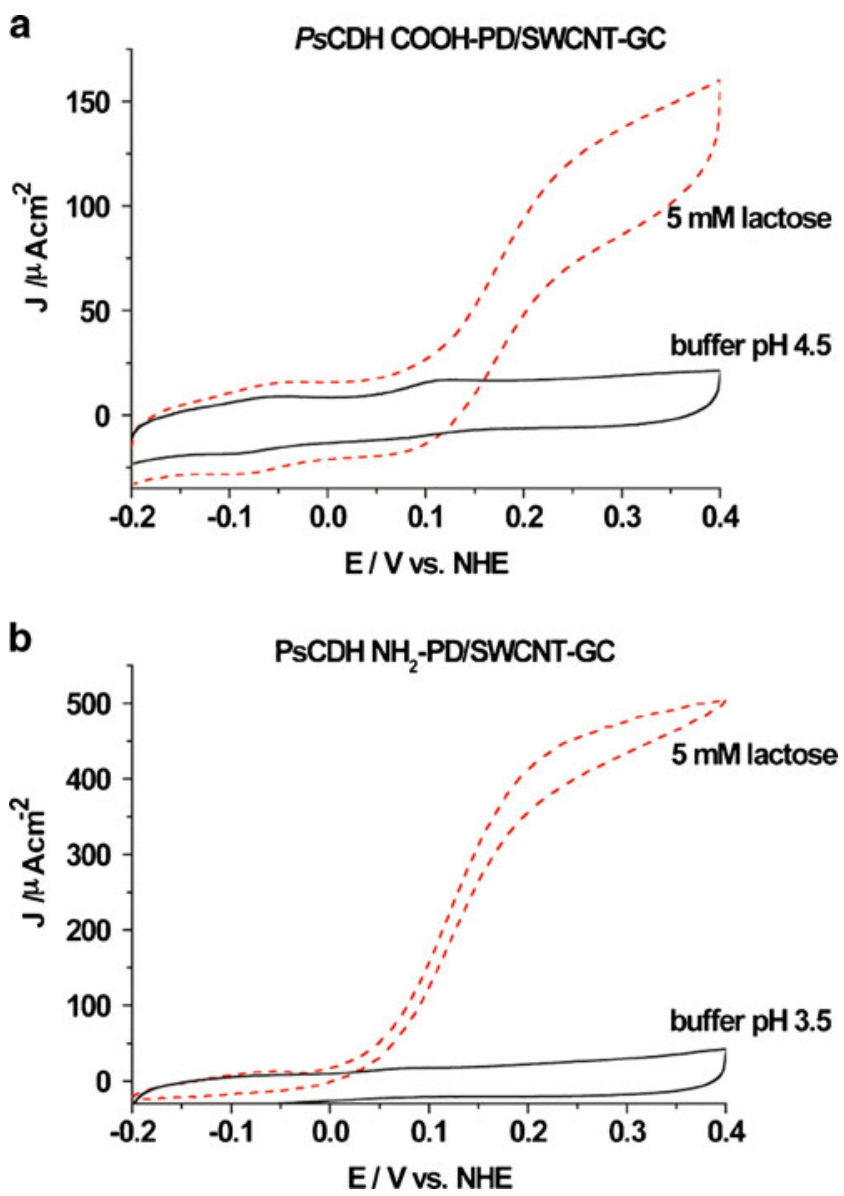

Fig. 6 a $\mathrm{CV}$ of a $P$. sordida $\mathrm{CDH} \mathrm{COOH}-\mathrm{PD} / \mathrm{SWCNT}-\mathrm{GC}$ electrode in the presence of $5 \mathrm{mM}$ lactose (red dashed line) and in the absence of substrate (black line) at $\mathrm{pH}$ 4.5. b CV of a P. sordida $\mathrm{CDH} \mathrm{NH}_{2-}$ $\mathrm{PD} / \mathrm{SWCNTs}-\mathrm{GC}$ electrode in the presence of $5 \mathrm{mM}$ lactose (red dashed line) and in the absence of substrate (black line) at $\mathrm{pH} 3.5$. Scan rate $1 \mathrm{mV} \mathrm{s}^{-1}$. Reproduced from [47] with permission from The American Chemical Society

governed by a combination of different effects: (i) hydrophilic/hydrophobic interactions between the SAM and the enzyme that control the orientation on the electrode surface, e.g. interactions between the $\mathrm{CDH}$ cellulose binding domain with $-\mathrm{OH}$ terminated alkanethiols, as the cellulose binding domain has a strong affinity for naturally occurring hydroxyl groups present on cellulose [60], but also electrostatic interactions between oppositely charged SAMs and the surface of the enzyme; (ii) a dependency of the rate of ET on the distance between the electrode and the enzyme, described by the Marcus theory $[105,106]$; and (iii) the compactness of the SAM, e.g. a densely packed SAM will slow down ET with the electrode.

Recently a series of investigations were performed on the interaction between various CDHs on gold and AuNPmodified solid gold electrodes [44, 48, 49, 51, 94]. In one study the effect of mutations close to the active site of study two different class II CDHs was investigated (Ortiz et al. submitted). In another study two class I CDHs were investigated [94], the focus being the effect of glycosylation/deglycosylation on the efficiency of DET. An exhaustive electrochemical investigation was performed on a number of class II CDHs (Neurospora crassa, C. thermophilus, Humicola insolens) and variants for improved glucose oxidation of $C$. thermophilus and $H$. insolens $\mathrm{CDH}$ using different aliphatic and aromatic thiols with varying head group functionalities $\left(-\mathrm{NH}_{2},-\mathrm{COOH}\right.$ and $\left.-\mathrm{OH}\right)$ and varying spacer lengths $(2,6$ and 11 carbons) or a phenyl group [44] (Ortiz et al. submitted). For all CDHs tested electrodes with SAMs based on $-\mathrm{OH}$ functionalised thiols exhibited high electrocatalytical currents. In the case of $N$. crassa $\mathrm{CDH}$ the electrocatalytical currents became higher and the separation between the anodic and cathodic peak potentials $\left(\Delta E_{\mathrm{p}}\right)$ of the $\mathrm{CYT}_{\mathrm{CDH}}$ decreased when the $-\mathrm{OH}$ functionalised alkanethiol increased in length (Fig. 7) [44]. For C. thermophilus $\mathrm{CDH}$ the effect was the opposite and even more pronounced (Ortiz et al. submitted). $H$. insolens $\mathrm{CDH}$ showed in general small and poorly defined catalytical currents, but quasi-reversible CVs. The highest electrocatalytical responses for $H$. insolens, $N$. crassa and C. thermophilus $\mathrm{CDH}$ were found for mercaptohexanol, mercaptobenzoic acid and mercaptoethanol-based SAMs, respectively. $N$. crassa $\mathrm{CDH}$ also showed catalytic currents and a small $\Delta E_{\mathrm{p}}$ for the thiols containing a phenyl group as spacer. On the other hand C. thermophilus $\mathrm{CDH}$ showed poor electrochemistry with such thiols. In another recent paper the electrochemistry of $P$. chrysosporium $\mathrm{CDH}$ was compared using four different thiols with $-\mathrm{OH}$ and $\mathrm{COOH}$ head groups and different spacers [48]. In accordance with previous reports, the highest electrocatalytical currents for this class I CDH was found for mercaptoundecanol (MUOH). Interestingly, a lower current density was found for the equivalent thiol having a $-\mathrm{COOH}$ functionality (mercaptundecanoic acid, MUA). The reason could be electrostatic repulsion between the negatively charged $\mathrm{CDH}$ and the $-\mathrm{COO}^{-}$group. Harreither et al. [45] studied the $E^{\circ \prime}$ and the electrocatalytical activity of C. thermophilus $\mathrm{CDH}$ using thioglycerol at different $\mathrm{pHs}$. The formal potential found, $100 \mathrm{mV}$ vs. NHE, is the lowest reported so far for all investigated class II CDHs [45]. It can be concluded that the choice of the thiol is critical. Clear effects of the spacer length and the functional head group are observed.

When native, glycosylated, and deglycosylated CDH from $P$. chrysosporium and $C$. subvermispora, denoted $P c \mathrm{CDH}, \operatorname{dg} P c \mathrm{CDH}$ and $C s \mathrm{CDH}, \operatorname{dg} C s \mathrm{CDH}$, respectively, were tested on an MUOH-based SAM, a higher current density was found for $\operatorname{dg} C s \mathrm{CDH}$ than for $\mathrm{Cs} \mathrm{CDH}$, but for $\mathrm{dg} P c \mathrm{CDH}$ and $P c \mathrm{CDH}$ a similar current density was found [94]. The likely reason is that native $C s \mathrm{CDH}$ is much more glycosylated than $P c \mathrm{CDH}$ so that the effect of deglycosylation is more pronounced for $\mathrm{Cs} \mathrm{CDH}$. 

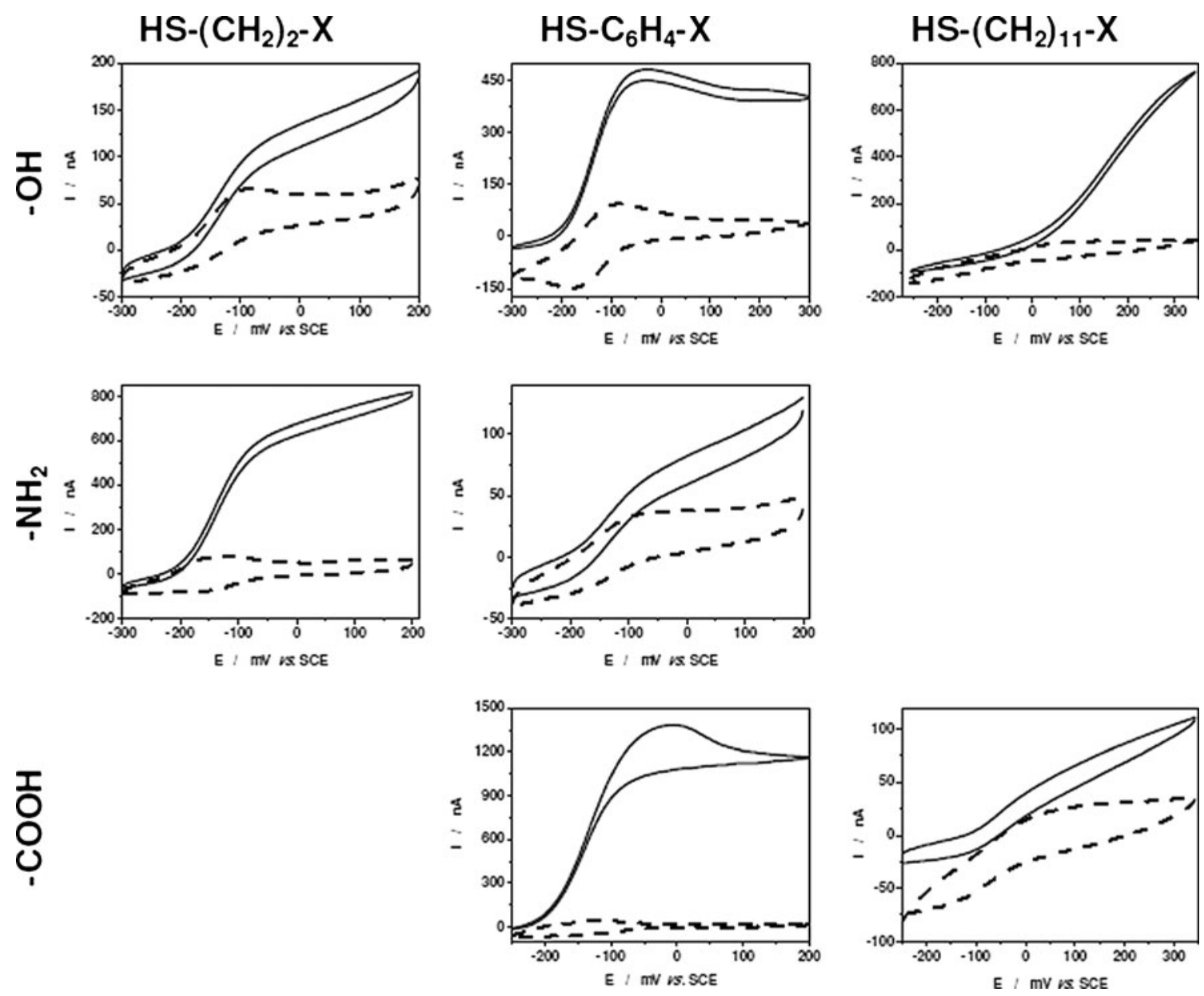

Fig. 7 Voltammetric responses of Au-mixed monolayer based SAMNeurospora crassa $\mathrm{CDH}$ modified electrodes in absence (dashed line) and in presence (solid line) of $5 \mathrm{mM}$ lactose. Experimental conditions:

\section{Mixed thiol SAMs}

Since the first bioelectrochemical studies on $\mathrm{CDH}$ in the late 1990s most studies have focused on the electrocatalytical activity. CV waves are not really observable on graphite electrodes modified with $\mathrm{CDH}$ owing to their high capacitive current. On the other hand, non-covalent interactions between $\mathrm{CDH}$ from different sources and gold electrodes or SAM-modified gold electrodes, and where the enzyme was retained behind a permselective membrane, has not shown stable electrochemical CV signals [102-104]. Efforts during recent years have focused on covalently immobilising $\mathrm{CDH}$ on alkanethiol-modified $\mathrm{Au}$ electrodes to avoid the usage of the permselective membrane [74, 102-104]. Matsumura et al. [48] compared immobilised $\mathrm{CDH}$ on four different SAMs based on two mixed thiols, where one of the head groups was $-\mathrm{NH}_{2}$ and the other $-\mathrm{COOH}$ or $-\mathrm{OH}$. GA was used to cross-link $P$. chrysosporium $\mathrm{CDH}$ to the amino group of the SAM. Matsumura et al. [48] used this approach to compare 11 different alkyl carbon chain based thiols as scan rate, $10 \mathrm{mV} / \mathrm{s}$; supporting electrolyte, $50 \mathrm{mM}$ citrate buffer $\mathrm{pH}$ 5.5. Reproduced from [44] with permission from Revue Roumaine de Chimie (Roumanian Journal of Chemistry)

well as one incorporating a phenyl group as spacer and the head groups $-\mathrm{OH}$ with $-\mathrm{COOH}$ [48]. The ratio of the alkanethiol mixture $(1: 50 \mathrm{v} / \mathrm{v})$ and GA $(0.25 \%)$ was optimised. The optimal ratio of the mixture for deglycosylated P. chrysosporium $\mathrm{CDH}$, which has a smaller radius than its glycosylated form, was 1:40. This suggests that the surrounding glycosyl residues and the radius of the $\mathrm{CDH}$ have an effect [94]. This immobilisation protocol was also used in a 3D mesoporous structure created by drop-casting AuNPs on the surface of $\mathrm{Au}$ disk electrodes based on previous work by Murata et al. [95]. The $k_{\mathrm{s}}$ values for AuNP/SAM/GA/ $P c \mathrm{CDH}$ were lower for the mixture of thiols having a phenyl spacer than those based on the 11-carbon alkane spacer. The rate-limiting step of the overall ET was the DET between the $\mathrm{CYT}_{\mathrm{CDH}}$ and the electrode instead of the IET from $\mathrm{DH}_{\mathrm{CDH}}$ to $\mathrm{CYT}_{\mathrm{CDH}}$ as measured by stoped-flow experiments. An overview of the current densities and $k_{\mathrm{s}}$ values is given in Table 4.

The same immobilisation procedure was applied for immobilising C. thermophilus CDH on AuNP-modified 
Table 4 Performance of $P$. chrysosporium $\mathrm{CDH}$ on mixed SAMs

\begin{tabular}{lllllll}
\hline Mixed SAMs & \multicolumn{2}{l}{ Polycrystalline gold } & \multicolumn{2}{l}{ AuNPs } & \multicolumn{2}{c}{ SPR } \\
\cline { 4 - 6 } & $J\left(\mu \mathrm{A} \mathrm{cm}^{-2}\right)$ & $J\left(\mu \mathrm{A} \mathrm{cm}^{-2}\right)$ & $E^{\circ \prime}(\mathrm{mV})$ & $\Delta E(\mathrm{mV})$ & $k_{\mathrm{s}}\left(\mathrm{s}^{-1}\right)$ & $\Gamma\left(\mathrm{pmol} \mathrm{mm}^{-2}\right)$ \\
\hline 4-ATP/4-MP & 0.26 & 4.0 & 161.7 & 14.7 & 59.8 & 5.79 \\
4-ATP/4-MBA & 0.40 & 29.3 & 161.5 & 14.6 & 52.1 & 5.71 \\
$\mathrm{MUNH}_{2} / \mathrm{MUOH}$ & 0.34 & 11.6 & 161.8 & 14.7 & 154.0 & 5.67 \\
$\mathrm{MUNH}_{2} / \mathrm{MUA}$ & 0.49 & 15.2 & 161.3 & 14.6 & 112.0 & 5.65 \\
\hline
\end{tabular}

Current densities, $J$, surface coverage, $\Gamma, k_{\mathrm{s}}$ and $E^{\circ \prime}$ for covalently attached CDH onto mixed SAMs. $J$ for polycrystalline gold and AuNPs were obtained at $300 \mathrm{mV}$ vs. NHE. Formal potentials, $E^{\circ}$, and peak separations, $\Delta E$, at $0.2 \mathrm{~V} \mathrm{~s}^{-1}$

ATP 4-aminothiophenol, $M P$ 4-mercaptophenol, $M B A$ 4-mercaptobenzoic acid, $M U N H_{2}$ mercapto-1-undecamine, $M U O H$ 11-mercapto-1-undecanol, MUA 11-mercapto-1-undecanoic acid, SPR surface plasmon resonance

Au disk and Au wire electrodes [49, 51]. The optimum GA amount $(1 \%)$ was higher than when using planar disk electrodes $(0.25 \%)$ [48], perhaps caused by the nanoparticle curvature but also because of using another $\mathrm{CDH}$. A onecompartment mediator-less glucose $/ \mathrm{O}_{2}$ biofuel cell (BFC) working under physiological conditions was established using such a bioanode based on C. thermophilus CDH in combination with a biocathode based on BOx [49]. The $\mathrm{BFC}$ had an open-circuit voltage of $0.68 \mathrm{~V}$ and a maximum power density of $15 \mu \mathrm{W} \mathrm{cm}{ }^{-2}$ at a cell voltage of $0.52 \mathrm{~V}$ in phosphate buffer and an open-circuit voltage of $0.65 \mathrm{~V}$ and a maximum power density of $3 \mu \mathrm{W} \mathrm{cm}{ }^{-2}$ at a cell voltage of $0.45 \mathrm{~V}$ in human blood. The estimated half-lives of the biodevices were greater than 12, less than 8 and less than $2 \mathrm{~h}$ in a sugar-containing buffer, human plasma and blood, respectively. The basic characteristics of mediator-less sugar/oxygen BFCs were significantly improved compared with previously designed biodevices [50,87], because of the usage of 3D AuNP-modified electrodes.

\section{Influence of cations on the activity of $\mathrm{CDH}$}

A screening of the influence of various metal cations on the activity of CDH was done in 1999 for the basidiomycete Schizophyllum commune in solution [107]. The highest increase in cyt $c$ activity by $8 \%$ was caused by the presence of $2 \mathrm{mM} \mathrm{Cu}^{2+}$ and the highest decrease by $70 \%$ was caused by the presence of $2 \mathrm{mM} \mathrm{Ag}^{+}$, thereby showing the ability of cations to modulate the activity of $\mathrm{CDH}$. A further study with immobilised $P$. chrysosporium $\mathrm{CDH}$ on a spectrographic graphite electrode showed a $50 \%$ increase in the catalytic current for lactose and cellobiose following the addition of $80 \mathrm{mM} \mathrm{NaCl}$ to the buffer [108]. The molecular interactions behind this observation are unknown, but it was excluded that an increased $\mathrm{CDH} /$ electrode interaction was the reason.

Recently the influence of cations on the activity of two class II CDHs from Myriococcum thermophilum and
Humicola insolens and one class I CDH from P. chrysosporium was investigated in more detail in solution and when immobilised on spectrographic graphite electrodes [109]. When immobilised on the graphite electrode the DET current for $M$. thermophilum $\mathrm{CDH}$ was most tunable by addition of $\mathrm{CaCl}_{2}$ in the millimolar range and exhibited up to a fivefold increase in the catalytic currents (Fig. 8a). The DET current of $H$. insolens CDH-modified electrodes was enhanced fourfold, but for $P$. chrysosporium $\mathrm{CDH}$ only 2.4fold. The exchange of $\mathrm{CaCl}_{2}$ by $\mathrm{MgCl}_{2}$ tuned the DET current in a similar manner. However, $\mathrm{KCl}$ had a much lower effect and enhanced DET currents by a maximum of twofold for M. thermophilum CDH. Activity assays based on cyt $c$ were used to investigate the modulation of the IET of $M$. thermophilum and $H$. insolens $\mathrm{CDH}$ in solution. Similar dependencies of the cyt $c$ activities on $\mathrm{CaCl}_{2}$ were observed as for the immobilised CDHs. The separately expressed $\mathrm{DH}_{\mathrm{CDH}}$ from $H$. insolens showed no cyt $c$ activity and no dependency on any added cations. Similarly, the DCIP activity of $H$. insolens $\mathrm{DH}_{\mathrm{CDH}}$ was completely independent of added $\mathrm{CaCl}_{2}$ or $\mathrm{KCl}$. It can be concluded that divalent cations increase either the interaction between the $\mathrm{DH}_{\mathrm{CDH}}$ and $\mathrm{CYT}_{\mathrm{CDH}}$ domains or between the CYT $\mathrm{CDH}$ domain and the final electron acceptor, which can be cyt $c$ or an electrode.

\section{Polyethylenimine as a promoter layer}

In analogy to the enhancing effect of $\mathrm{CaCl}_{2}$, a currentincreasing effect of the branched polycation polyethylenimine (PEI) as a promoter layer was anticipated for the construction of $\mathrm{CDH}$-modified biosensors. Beneficial effects have been shown in several publications covering, for example, cyt $c$ on carbon electrodes [110], the detection of NADH with phenoxazine derivative modified carbon paste electrodes [111, 112] and some other redox enzyme modified carbon paste electrodes [113-117] or improved electrochemistry of human sulfite oxidase on PEI-modified 
Fig. 8 Variation of response current (I) with the applied potential (E) of spectrographic graphite electrodes modified with Myriococcum thermophilum $\mathrm{CDH}(\mathbf{a}, \mathbf{c})$ and optionally pre-modified with polyethylenimine (PEI) (b, d) in $50 \mathrm{mM}$ sodium acetate buffer pH $5.5(\mathbf{a}, \mathbf{b})$ or $50 \mathrm{mM}$ TRIS $\mathrm{pH} 8.0(\mathbf{c}, \mathbf{d})$ in the absence (white squares) or in the presence of $50 \mathrm{mM} \mathrm{CaCl}_{2}$ (black squares) with $5 \mathrm{mM}$ lactose as substrate. The inset in $\mathbf{c}$ shows a magnification of the response curve a
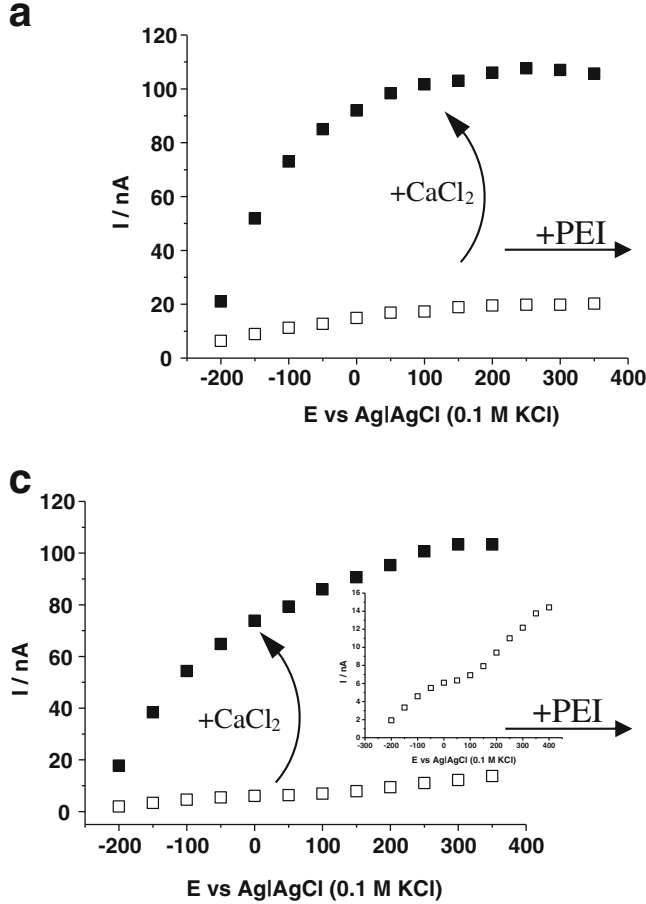

b
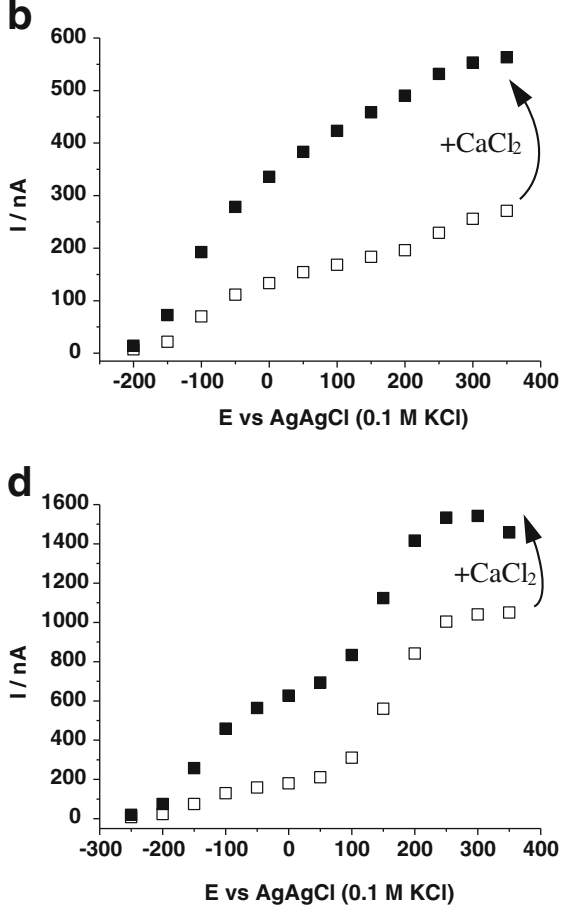

gold nanoparticles [118]. In recent work the influence of PEI as a promoter layer on spectrographic graphite electrodes modified with $M$. thermophilum $\mathrm{CDH}$ was investigated. The pre-modification of a graphite electrode with PEI increased the maximal catalytic current from the oxidation of $3.75 \mathrm{mM}$ lactose by around 13 times at $\mathrm{pH} 5.5$ (pH optimum) and by around 87 times at $\mathrm{pH} 8.0$ (Fig. 8). The modification with PEI also shifted the $\mathrm{pH}$ optimum from 5.5 to 8.0, which is interesting for biosensor applications measuring at human physiological $\mathrm{pH}$ (7.4). A further addition of $50 \mathrm{mM} \mathrm{CaCl}_{2}$ still shows enhancing effects, but is less pronounced in the presence of PEI. This indicates that PEI acts similarly to $\mathrm{CaCl}_{2}$. Another explanation would be an increased surface loading of $M$. thermophilum $\mathrm{CDH}$ on the PEI-modified electrode owing to strong electrostatic binding of CDH to PEI [19].

Besides the enhancing effect of PEI on the catalytic currents, the CVs unexpectedly revealed two catalytic redox waves. One starting at $-100 \mathrm{mV}$ vs. $\mathrm{Ag} \mid \mathrm{AgCl}(0.1 \mathrm{M} \mathrm{KCl})$ representing the expected $\mathrm{ET}$ from the $\mathrm{CYT}_{\mathrm{CDH}}$ domain to the electrode [74] and a second catalytic wave, most pronounced at $\mathrm{pH} 8.0$ and starting at around $100 \mathrm{mV}$, which is visible even in the absence of PEI (Fig. 8c, inset). The origin of the second catalytic wave is unknown, but has been observed before for P. chrysosporium CDH [108] and is currently under investigation. However, the enhancing effect of PEI is also clearly present at potentials below the second catalytic wave. Until now the beneficial effect of PEI was only observed for class II $M$. thermophilum $\mathrm{CDH}$. The catalytic responses of class II $N$. crassa $\mathrm{CDH}$ and class I $P$. chrysosporium $\mathrm{CDH}$ could not be improved by the premodification of graphite electrodes with PEI. This is probably because the latter CDHs already have a more efficient DET and/or IET compared to that of M. thermophilum $\mathrm{CDH}$ [43, 88, 119].

\section{Deglycosylation}

Deglycosylation of enzymes has been used to facilitate the electron transfer and even to achieve DET from deeply buried prosthetic groups of redox enzymes, even from deeply buried FAD in e.g. Aspergillus niger glucose oxidase (GOx) [120-123]. CDH is a glycoprotein that shows a glycosylation between 8 and $16 \%$ [19] depending on the organism used for expression. The carbohydrate chains are believed to stabilise the tertiary protein structure and increase the solubility of the protein molecule. A voluminous carbohydrate structure on the enzyme surface will act as an insulator for enzymes attached to electrodes [120]. Opposed to what was found for GOx and pyranose dehydrogenase, deglycosylation of $\mathrm{CDH}$ did not result in any DET between the $\mathrm{FAD}$ in the $\mathrm{DH}_{\mathrm{CDH}}$ domain and an electrode. However, the catalytic current densities increased two- to threefold in the presence of lactose, for deglycosylated $P$. chrysosporium (9 \% glycosylated) and C. subvermispora $\mathrm{CDH}$ (16\% glycosylated) compared with their glycosylated counterparts when adsorbed on spectrographic graphite electrodes (Fig. 9) [94]. The apparent Michaelis-Menten constant $K_{\mathrm{M}}^{\text {app }}$ for lactose was also found to decrease by two- to threefold for the deglycosylated CDHs compared to the glycosylated 

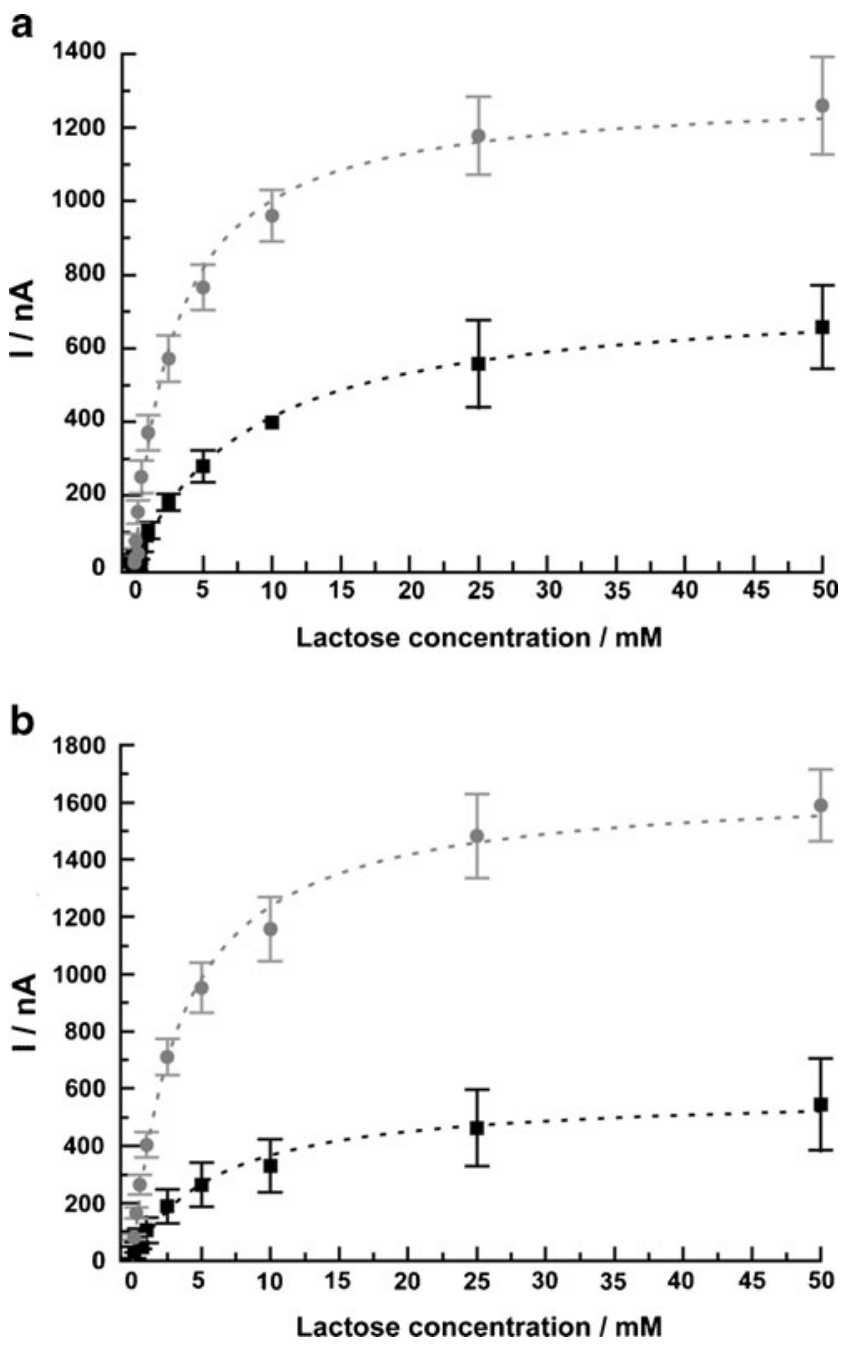

Fig. 9 Dependence of the amperometric response on lactose concentration of a glycosylated Phanerochaete chrysosporium $\mathrm{CDH}$ (squares) and deglycosylated P. chrysosporium $\mathrm{CDH}$ (circles) and $\mathbf{b}$ glycosylated Ceriporiopsis subvermispora CDH (squares) and deglycosylated $C$. subvermispora $\mathrm{CDH}$ (circles) in acetate buffer ( $\mathrm{pH} 4.5)$. The applied potential was $+150 \mathrm{mV}$ vs. $\mathrm{Ag} \mid \mathrm{AgCl}(0.1 \mathrm{M} \mathrm{KCl})$ and the flow rate of the solution $(\mathrm{pH} 4.5)$ was $1 \mathrm{~mL} \mathrm{~min}^{-1}$. The results were obtained in a flow-injection system. Reproduced from [94] with permission from The American Chemical Society

ones. When the enzymes were compared trapped under a permselective membrane and 11-mercaptoundecanol (MUOH) SAM-modified $\mathrm{Au}$ disk electrodes, glycosylated and deglycosylated P. chrysosporium $\mathrm{CDH}$ showed the same catalytic activity, whereas glycosylated and deglycosylated $C$. subvermispora $\mathrm{CDH}$ showed similar results to that obtained on spectrographic graphite electrodes, i.e. a much higher catalytic current was found when using the deglycosylated form. The $E^{\circ \prime}$ for the deglycosylated $\mathrm{CDH}$ was found to shift up by $\sim 8 \mathrm{mV}$. In a different study glycosylated and deglycosylated $T$. villosa $\mathrm{CDH}$ were compared when immobilised on an LbL supramolecular architecture stabilised by electrostatic interaction between the layers. Au wire electrodes were first modified with a mixed monolayer of $\mathrm{MUOH}$ and MUA. Then successively alternating layers of carboxy-terminated SiNPs and a mixture of cyt $c$ and T. villosa $\mathrm{CDH}$ were added and a supramolecular structure was built up to four bilayers. Using this technique, Feifel et al. [52] found a maximum increase of seven times higher faradaic currents in the presence of lactose as substrate for the deglycosylated variant. The results suggest that the increase in current density is attributed to an increase in the amount of molecules packed on the electrodes, i.e. to a more compact packing of $\mathrm{CDH}$ on the electrode surface and in the layers.

\section{Mediated electron transfer}

Even though a system based on DET is, from a fundamental point of view, more interesting than one based on MET, there are limitations to the current density that can be reached with DET. Even though it should be possible to immobilise multilayers of a redox enzyme with DET properties, it is expected that primarily only the innermost layer of enzyme molecules on the electrode surface will be able to electrochemically communicate with the electrode. However, through the use of nanostructured electrodes and with $\mathrm{CDH}$ oriented for improved DET [47-49] the current density can be largely increased compared with that obtained with conventional electrodes. Moreover, as DET between $\mathrm{CDH}$ and an electrode is obtained through the $\mathrm{CYT}_{\mathrm{CDH}}$, which has an $E^{\circ \prime}$ value much more positive than that of the FAD of the $\mathrm{DH}_{\mathrm{CDH}}[74,124]$, in a $\mathrm{BFC}$ anode based on MET using a mediator with an $E^{\circ \prime}$ much lower than that of the $\mathrm{CYT}_{\mathrm{CDH}}$ (and close to that of the $\mathrm{DH}_{\mathrm{CDH}}$ ), both the power output and the current density can be largely improved [89, 91, 93, 125]. An overview of MET approaches with $\mathrm{CDH}$ was given in 2010 [19]. Since then mainly two directions have been followed. The first is the combination of $\mathrm{CDH}$ with cyt $c$ as a mediator in an LbL approach, as discussed separately above. The second is the further development and application of osmium polymers, which were first applied together with CDH as early as 1992 [126] on the basis of the work by Heller and co-workers [127, 128]. Similar to the use of other sugar-oxidising redox enzymes in biosensors and biofuel cells [129-136], the "wiring" of various $\mathrm{CDHs}$ with Os-redox polymers accepting electrons direct from the $\mathrm{DH}_{\mathrm{CDH}}$ is very promising for obtaining high current densities at low potentials [46, 90, 91, 93, 125]. During the last few years particular focus was given to electrodeposited Os-polymers (OsEDPs), which contain, in addition to the polymeric backbone and the redox-active Os-complex, either one or more $\mathrm{COO}^{-}$or $\mathrm{NH}_{3}{ }^{+}$groups. Deposition of those 
polymers is achieved by local changes of the $\mathrm{pH}$ at the electrode surface caused by either electrolysis or change of buffer, resulting in discharged and insoluble Ospolymers that precipitate on the electrode surface. Schuhmann and co-workers $[125,137]$ synthesised and investigated 50 different Os-EDPs having redox potentials ranging from -430 to $+667 \mathrm{mV}$ vs. $\mathrm{Ag} \mid \mathrm{AgCl}$. Ospolymer-mediated electron transfer was shown for $\mathrm{CDH}$, glucose oxidase and PQQ-dependent glucose dehydrogenase suitable for biofuel cell anodes and for laccase and BOx suitable for corresponding cathodes [125, 137]. In a recent paper a bi-enzyme bioanode modified with an Os-DEP, the separate $\mathrm{DH}_{\mathrm{CDH}}$ of $C$. thermophilus and pyranose dehydrogenase (PDH) from Agaricus meleagris were investigated for the multiple oxidation of glucose [46]. As CDH oxidises its substrate at the $\mathrm{C} 1$ it is only possible to gain two electrons per substrate molecule. However, if $\mathrm{CDH}$ is combined with $\mathrm{PDH}$ it is possible to obtain up to six electrons per substrate molecule, as PDH oxidises the sugar substrate at either $\mathrm{C} 2$ or $\mathrm{C} 3$ or both and the product when the substrate is oxidised by $\mathrm{CDH}$ is a substrate for $\mathrm{PDH}$ and vice versa. Figure 10 outlines how glucose can be oxidised at an anode where $C$. thermophilus $\mathrm{CDH}$ is co-immobilised with Agaricus meleagris PDH yielding six electrons instead of only two.

However, conventional mediators such as $p$-benzoquinone (BQ) are still in use as well. When comparing the efficiency of DET for a CDH-modified electrode in relation to MET it is quite convenient to use BQ dissolved in the buffer. This approach has been used previously [88] and was also used for the characterisation of various CDHs [45], especially for $N$. crassa CDH immobilised on spectrographic graphite electrodes with various substrates at $\mathrm{pH} 5.2$ and 7 [43]. A biosensor for the real-time measurement of cellobiohydrolase activity was established by Cruys-Bagger and co-workers [54] using a BQ-containing carbon paste electrode modified with cross-linked $P$. chrysosporium $\mathrm{CDH}$. The sensor detected cellobiose with a sensitivity of $87.7 \mu \mathrm{A}$

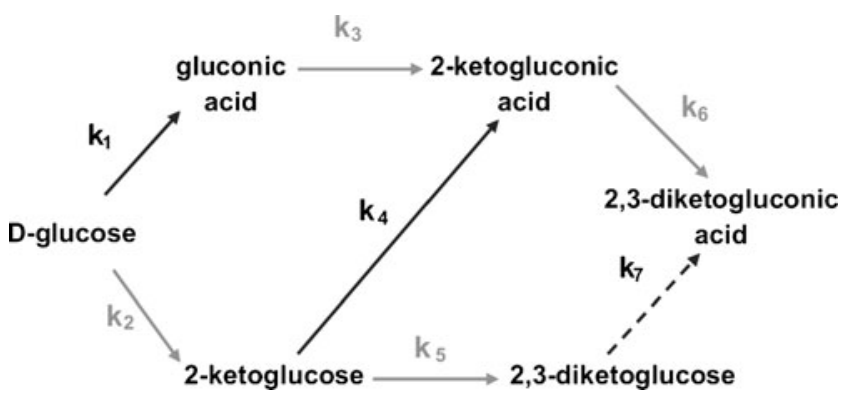

Fig. 10 Reaction pathway of glucose oxidation by a bi-enzymatic system consisting of $\mathrm{CDH}$ (C1 oxidation, black arrows) and Agaricus meleagris $\mathrm{PDH}$ (C2 and $\mathrm{C} 3$ oxidation, grey arrows). Reproduced from [46] with permission from Elsevier
$\mathrm{mM}^{-1} \mathrm{~cm}^{-2}$, a low detection limit of $25 \mathrm{nM}$ and a response time of ca. $3 \mathrm{~s}$.

\section{Application of CDH in biosensors}

CDH was used in two ways in biosensors: either to detect the oxidation of carbohydrates or reduce quinones and catecholamines for signal amplification in an oxidative electrode setup. In a recent review the application of $\mathrm{CDH}$ in biosensors until 2010 is described in detail [19]; here we give an overview of developments in the few last years (Table 5). Depending on the source of $\mathrm{CDH}$, specific catalytic properties allow the oxidation of different substrates by different CDHs and therefore different analytes in terms of biosensor applications. Class I CDHs show a very high specificity for $\beta$-1,4-linked substrates and are therefore ideal bioelements for the detection of cellobiose and lactose. But it has to be considered that these CDHs work only efficient under acidic $\mathrm{pH}$ conditions. Very sensitive lactose sensors based on class I CDH have been developed for use in the dairy industry; these have a detection limit down to $250 \mathrm{nM}$, which corresponds to $90 \mu \mathrm{g} \mathrm{L}^{-1}[55,58,85]$. In a different approach a lactose biosensor was developed by the combination of the thermometric signal from lactose oxidation with the amperometric signal of the enzymatic reaction [138]. In contrast to the third-generation biosensor reported by Safina et al. [55], the amperometric signal was based on the reduction of hydroquinone, which is formed during the oxidation of lactose by $\mathrm{CDH}$.

In another recent example, a $\mathrm{CDH}$ biosensor was designed to measure the cellobiohydrolase activity on insoluble cellulose [54]. The ability of CDH to oxidise cellobiose- the reaction product of cellobiohydrolase - was used to monitor the transient kinetics of cellobiohydrolase. The approach could be validation by HPLC analysis and represents an interesting real-time method to monitor cellulase activity. The discovery that class II CDHs are able to oxidise the monosaccharide glucose opened the door to designing a third-generation glucose biosensor [88]. Beside their altered substrate specificity, class II CDHs are not restricted to work under acidic $\mathrm{pH}$ conditions. Probably the most interesting candidate for a glucose biosensor is the $\mathrm{CDH}$ from $C$. thermophilus because the highest DET rates were found under human physiological $\mathrm{pH}$ conditions [45]. The third-generation glucose biosensor based on $\mathrm{CDH}$ showed a linear range between 0.1 and $30 \mathrm{mM}$, which makes it suitable for measuring blood glucose levels [47, 57]. This $\mathrm{CDH}$ should allow the construction of a simple glucose biosensor which does not depend on oxygen or any other artificial redox mediators and therefore represents an interesting alternative to established biosensors based on glucose 
Table 5 CDH-based biosensors

\begin{tabular}{|c|c|c|c|c|c|c|c|}
\hline Analyte & $\begin{array}{l}\text { Detection } \\
\text { limit }\end{array}$ & 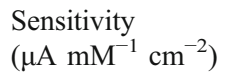 & $\begin{array}{l}\text { Mediator/ } \\
\text { enhancer }^{\mathrm{a}}\end{array}$ & $\begin{array}{l}\text { Electrode } \\
\text { modification }\end{array}$ & Electrode material & $\mathrm{CDH}$ & Reference \\
\hline Noradrenaline & $1 \mathrm{nM}$ & 15,800 & Cellobiose & Adsorption & SG & $P c \mathrm{CDH}$ & {$[85]$} \\
\hline Catechol & $1 \mathrm{nM}$ & 9,500 & Cellobiose & Adsorption & SG & $P c \mathrm{CDH}$ & {$[85]$} \\
\hline Hydroquinone & $0.75 \mathrm{nM}$ & 11,140 & Cellobiose & Adsorption & SG & $P c \mathrm{CDH}$ & {$[85]$} \\
\hline L-Adrenaline & $5 \mathrm{nM}$ & 1,140 & Cellobiose & Adsorption & SG & $P c \mathrm{CDH}$ & {$[85]$} \\
\hline $\begin{array}{l}\text { 3-Hydroxylamine } \\
\text { hydrochloride }\end{array}$ & $2.5 \mathrm{nM}$ & 9,160 & Cellobiose & Adsorption & SG & $P c \mathrm{CDH}$ & {$[85]$} \\
\hline $\begin{array}{l}\text { 3,4-Hydroxyphenylacetic } \\
\text { acid }\end{array}$ & $1 \mathrm{nM}$ & 13,440 & Cellobiose & Adsorption & SG & $P c \mathrm{CDH}$ & {$[85]$} \\
\hline Lactose & $1 \mu \mathrm{M}$ & 17.8 & No & Adsorption & SG & $\mathrm{Tv} \mathrm{CDH}$ & {$[85]$} \\
\hline Lactose & $1 \mu \mathrm{M}$ & 11.0 & No & Adsorption & SG & $P s \mathrm{CDH}$ & {$[85]$} \\
\hline Lactose & $1 \mu \mathrm{M}$ & 1.06 & No & Adsorption & SG & $M t \mathrm{CDH}$ & [88] \\
\hline Lactose & $1 \mu \mathrm{M}$ & 2.8 & No & Adsorption & SCE & $M t \mathrm{CDH}$ & [149] \\
\hline Lactose & $1 \mu \mathrm{M}$ & 0.38 & No & PANI+adsorption & SCE & $M t \mathrm{CDH}$ & [149] \\
\hline Lactose & $250 \mathrm{nM}$ & NG & No & Cross-linked & SCE & $P s \mathrm{CDH}$ & {$[55,58]$} \\
\hline Lactose & $50 \mu \mathrm{M}$ & NG & BQ & Covalent binding & $\mathrm{CPG}$ & Rec. Pc $\mathrm{CDH}$ & [138] \\
\hline Cellobiose & $25 \mu \mathrm{M}$ & 0.8 & No & Adsorption & SG & $P c \mathrm{CDH}$ & {$[150]$} \\
\hline Cellobiose & $25 \mu \mathrm{M}$ & 23 & Os-polymer & Entrapment & SG & $P c \mathrm{CDH}$ & {$[150]$} \\
\hline Cellobiose & $0.5 \mu \mathrm{M}$ & 1.85 & No & Adsorption & SG & $M t \mathrm{CDH}$ & [88] \\
\hline Cellobiose & $25 \mathrm{nM}$ & 87.7 & Hydroquinone & Cross-linked & SG & Rec. Pc $\mathrm{CDH}$ & {$[54]$} \\
\hline Glucose & $1 \mathrm{mM}$ & 0.0068 & No & Adsorption & SG & $M t \mathrm{CDH}$ & [88] \\
\hline Glucose & $0.05 \mathrm{mM}$ & 0.22 & No & $\begin{array}{l}\text { Cross-linked }+ \\
\text { SWCNTs }\end{array}$ & SG & $\mathrm{CtCDH}$ & {$[56]$} \\
\hline Glucose & $0.01 \mathrm{mM}$ & NG & No & $\begin{array}{l}\text { Cross-linked }+ \\
\text { SWCNTs }\end{array}$ & SCE & $\mathrm{CtCDH}$ & {$[57]$} \\
\hline
\end{tabular}

$S G$ spectroscopic graphite, $S C E$ screen-printed carbon electrode, $P A N I$ polyaniline, $C P E$ carbon paste electrode, $R e c$. recombinant, $N G$ value not given

${ }^{a}$ To increase the signal of catecholamines the enzyme's carbohydrate substrate was applied for signal amplification by recycling of the analyte

oxidase and glucose dehydrogenase. The main targets for optimising CDH-based biosensors recently focused on the increase in current densities leading to higher sensitivities by designing the interface between the electrode and the enzyme.

\section{Recent advances in CDH-based biofuel cell anode performance}

The initial work on BFC applications was based on spectroscopic graphite electrodes modified with adsorbed $\mathrm{CDH}$. The class I CDHs from P. chrysosporium [90, 93], T. villosa [125] and Dichomera saubinetii [87] and the class II CDHs from M. thermophilum [89, 90] and C. thermophilus [50] were used in these initial studies with lactose or glucose as the anodic fuel. In order to increase the current density in some of the studies, SWCNTs were also applied to increase the aspect ratio surface area to achieve higher loadings of adsorbed CDH [89, 90, 93]. Mediating Os-polymers were also applied to achieve a direct contact of the electrode with the $\mathrm{DH}_{\mathrm{CDH}}$ domain aiming at higher power densities gained at lower potentials [89, 91, 93]. To maximise the opencircuit voltage, it is desirable to have enzyme molecules in

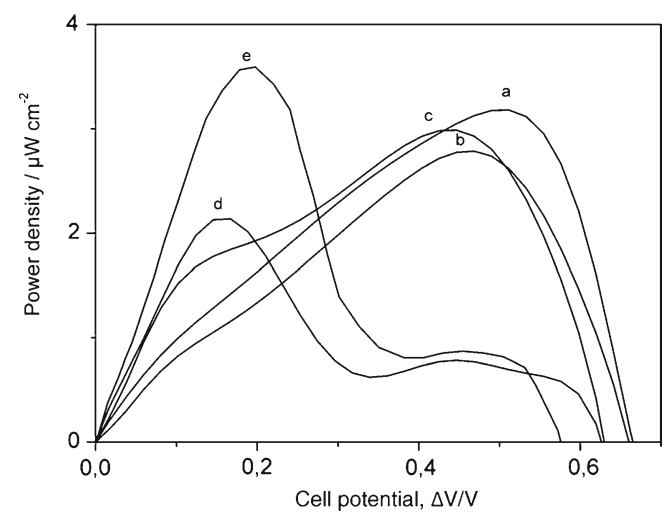

Fig. 11 Dependency of the power density on the operating voltage of a glucose $/ \mathrm{O}_{2}$ biofuel cell based on $\mathrm{Au}|\mathrm{AuNP}| \mathrm{Ct} \mathrm{CDH}||$ bilirubin oxidase $\mid$ $\mathrm{AuNP} \mid \mathrm{Au}$ under air-saturated quiescent conditions in $a \mathrm{PBS} \mathrm{pH} 7.4$, $5 \mathrm{mM}$ glucose; $b$ human blood; $c$ human plasma; $d$ unstimulated human saliva; $e$ human basal tears. Reproduced from [51] with permission from Elsevier 
DET communication with the electrode, in the absence of redox mediators. Most recently the focus for BFC-based setups using $\mathrm{CDH}$ has been on the use of gold nanoparticles (AuNPs). On the basis of the work by Murata et al. [95] on nanomodification of polycrystalline $\mathrm{Au}$ electrodes with AuNPs, a covalent immobilisation technique for $\mathrm{CDH}$ was developed by Matsumura et al. [48] based on a SAM of mixed thiols, amino and hydroxyl or carboxylic acid terminated, and GA as a cross-linker. The technique was optimised and further used with a $C$. thermophilus $\mathrm{CDH}$-based anode in combination with a BOx-based cathode to construct a one-compartment, mediator-less BFC working under human physiological conditions with glucose $/ \mathrm{O}_{2}$ as the fuel [49]. The performance of the biodevice was evaluated in blood and plasma. In buffer containing glucose, the opencircuit potential was $0.66 \mathrm{~V}$ with a maximum power density of $3.3 \mu \mathrm{W} \mathrm{cm}{ }^{-2}$ at a cell voltage of $0.52 \mathrm{~V}$. The performance was only slightly reduced in the physiological fluids. The half-life was $30 \mathrm{~h}$ in buffer, $8 \mathrm{~h}$ in blood and $2 \mathrm{~h}$ in plasma. The same modification was used to fabricate a device tested in lachrymal fluid (tears) for possible future applications on non-invasive medical devices ex vivo [51]. The $\mathrm{CDH} / \mathrm{BOx} /$ AuNP-based nanodevice had an open-circuit potential of $0.57 \mathrm{~V}$ with a maximum power density of $3.5 \mu \mathrm{W} \mathrm{cm} \mathrm{cm}^{-2}$ at a comparably low operational voltage of $0.2 \mathrm{~V}$, probably owing to interferences with ascorbic acid and dopamine. At $0.5 \mathrm{~V}$ a maximum power density of only $0.8 \mu \mathrm{W} \mathrm{cm}{ }^{-2}$ was observed because of the low concentration of glucose in the lachrymal fluid. Figure 11 shows the performance of the $\mathrm{BFC}$ in the described buffers and physiological fluids.

\section{Conclusions and outlook}

$\mathrm{CDH}$ is an emerging biocatalyst for biosensors and biofuel cells. Its versatility originates from its unique molecular properties, but also from the catalytic heterogeneity of $\mathrm{CDHs}$ from different sources. Differences in the $\mathrm{pH}$ optima, the $\mathrm{pH}$ optima for IET, the substrate specificity, etc., span a wide range and provide a toolbox of CDHs for different tasks and applications. Over $20 \mathrm{CDHs}$ from different fungi have been characterised so far and recombinant expression techniques guarantee access to these enzymes. An issue of importance with $\mathrm{CDH}$ is, however, the microheterogeneity of enzyme preparations, especially glycoforms. Glycosyl residues alter the IET, but also the binding to electrode surfaces and the orientation on the electrode and are therefore an important factor to watch in future experiments. Another critical factor is the loading of FAD in recombinantly produced ascomycete CDHs. The substochioimetric presence of FAD in the $\mathrm{DH}_{\mathrm{CDH}}$ results in apparently lower turnover numbers and reduces the catalytic current. Alternative expression strategies or expression hosts should be tested for better results. The development of specifically modified electrode surfaces, either by chemical modification or by nanostructures, has tremendously increased the currents achievable with $\mathrm{CDH}-$ modified electrodes. A combination of the approaches from materials science and enzyme engineering will have great impact on the development of $\mathrm{CDH}$-modified electrodes with high current densities in the milliampere per square centimetre range. Such high current densities will ultimately allow miniaturisation of $\mathrm{CDH}$ electrodes down to single carbon fibre electrodes, which can be used in miniaturised biosensors for continuous on-site or point-of-care measurements. Finally, one should mention the exciting use of ionic liquids in combination with $\mathrm{CDH}$. Ionic liquids are potential candidates as non-aqueous solvents in this context and were shown to improve the shelf-life of CDH bound to AuNPs and carbon nanoparticles [151, 152].

Acknowledgments The authors thank the following agencies for financial support: the European Commission (project 3D-Nanobiodevice NMP4-SL-2009-229255, project Chebana FP7-PEOPLE-2010-ITN264772), the nmC@LU, the Swedish Research Council (project 6212010-5031), the Austrian Science Fund (translational project FWF L395B11) and the Austrian Academy of Science (APART project 11322) and the New Zealand Ministry of Innovation, Business and Enterprise (formerly the Ministry of Science and Innovation).

Open Access This article is distributed under the terms of the Creative Commons Attribution License which permits any use, distribution, and reproduction in any medium, provided the original author(s) and the source are credited.

\section{References}

1. Deepshikha, Basu T (2011) Anal Lett 44(6):1126-1171

2. Iost RM, Madurro JM, Brito-Madurro AG, Nantes IL, Caseli L, Crespilho FN (2011) Int J Electrochem Sci 6(7):2965-2997

3. Plowman BJ, Bhargava SK, O’Mullane AP (2011) Analyst 136 (24):5107-5119

4. Rahman MM, Ahammad AJS, Jin J-H, Ahn SJ, Lee J-J (2010) Sensors 10(5):4855-4886

5. Asefa T, Duncan CT, Sharma KK (2009) Analyst 134(10):1980 1990

6. Chen D, Wang G, Li JH (2007) J Phys Chem 111(6):2351-2367

7. Gooding JJ, Darwish N (2012) Chem Rec 12(1):92-105

8. Pingarron JM, Yanez-Sedeno P, Gonzalez-Cortes A (2008) Electrochim Acta 53(19):5848-5866

9. Shipway AN, Katz E, Willner I (2000) Chem Phys Chem 1(1):18-52

10. Xiao YH, Li CM (2008) Electroanalysis 20(6):648-662

11. Alferov S, Coman V, Gustavsson T, Reshetilov A, von Wachenfeldt C, Hägerhäll C, Gorton L (2009) Electrochim Acta 54(22):4979-4984

12. Baronian K, Downard A, Lowen R, Pasco N (2003) Appl Microbiol Biotechnol 60(1-2):108-113

13. Chelikani V, Downard AJ, Kunze G, Gooneratne R, Pasco N, Baronian KHR (2012) Electrochim Acta 73:136-140

14. Chelikani V, Rawson FJ, Downard AJ, Gooneratne R, Kunze G, Pasco N, Baronian KHR (2011) Biosens Bioelectron 26(9):37373741

15. Coman V, Gustavsson T, Finkelsteinas A, Von Wachenfeldt C, Hägerhäll C, Gorton L (2009) J Am Chem Soc 131(44):16171-16176 
16. Durand F, Kjaergaard CH, Suraniti E, Gounel S, Hadt RG, Solomon EI, Mano N (2012) Biosens Bioelectron 35(1):140 146

17. Hasan K, Patil SA, Górecki K, Leech D, Hägerhäll C, Gorton L (2012) Bioelectrochemistry. doi:10.1016/j.bioelechem.2012.05.004

18. Kostesha NV, Almeida JRM, Heiskanen AR, Gorwa-Grauslund MF, Hahn-Hägerdahl B, Emnéus J (2009) Anal Chem 81 (24):9896-9901

19. Ludwig R, Harreither W, Tasca F, Gorton L (2010) Chem Phys Chem 11(13):2674-2697

20. Patil SA, Hasan K, Leech D, Hägerhäll C, Gorton L (2012) Chem Commun 48(82):10183-10185

21. Rawson FJ, Garrett DJ, Leech D, Downard AJ, Baronian KHR (2011) Biosens Bioelectron 26(5):2383-2389

22. Rawson FJ, Gross AJ, Garrett DJ, Downard AJ, Baronian KHR (2012) Electrochem Commun 15(1):85-87

23. Katz E, Willner I (2004) Chem Phys Chem 5(8):1085-1104

24. Meredith MT, Minteer SD (2012) Annu Rev Anal Chem 5 (1):157-179

25. Osman MH, Shah AA, Walsh FC (2011) Biosens Bioelectron 26 (7):3087-3102

26. Willner I, Yan YM, Willner B, Tel-Vered R (2009) Fuel Cells 9 (1):7-24

27. Rabaey K, Rozendal RA (2010) Nat Rev Microbiol 8(10):706716

28. Barton SC, Gallaway J, Atanassov P (2004) Chem Rev 104 (10):4867-4886

29. Cracknell JA, Vincent KA, Armstrong FA (2008) Chem Rev 108 (7):2439-2461

30. Falk M, Blum Z, Shleev S (2012) Electrochim Acta 82:191202

31. Leger C, Bertrand P (2008) Chem Rev 108(7):2379-2438

32. Woolerton TW, Sheard S, Chaudhary YS, Armstrong FA (2012) Energ Environ Sci 5(6):7470-7490

33. Mowat CG, Gazur B, Campbell LP, Chapman SK (2010) Arch Biochem Biophys 493(1):37-52

34. Guo LH, Hill HAO (1991) Adv Inorg Chem 36:341-376

35. Hallberg BM, Bergfors T, Baeckbro K, Pettersson G, Henriksson G, Divne C (2000) Structure 8(1):79-88

36. Hallberg MB, Henriksson G, Pettersson G, Divne C (2002) J Mol Biol 315(3):421-434

37. Ikeda T, Kobayashi D, Matsushita F, Sagara T, Niki K (1993) J Electroanal Chem 361(1-2):221-228

38. Beeson WT, Phillips CM, Cate JHD, Marletta MA (2012) J Am Chem Soc 134(2):890-892

39. Langston JA, Shaghasi T, Abbate E, Xu F, Vlasenko E, Sweeney MD (2011) Appl Environ Microbiol 77(19):70077015

40. Li X, Beeson WT, Phillips CM, Marletta MA, Cate JHD (2012) Structure 20(6):1051-1061

41. Phillips CM, Beeson WT, Cate JH, Marletta MA (2011) ACS Chem Biol 6(12):1399-1406

42. Harreither W, Sygmund C, Augustin M, Narciso M, Rabinovich ML, Gorton L, Haltrich D, Ludwig R (2011) Appl Environ Microbiol 77(5):1804-1815

43. Kovacs G, Ortiz R, Coman V, Harreither W, Popescu IC, Ludwig R, Gorton L (2012) Bioelectrochemistry 88:84-91

44. Kovacs G, Ortiz R, Coman V, Harreither W, Popescu IO, Ludwig R, Gorton L (2012) Rev Roum Chim 57:361-368

45. Harreither W, Nicholls P, Sygmund C, Gorton L, Ludwig R (2012) Langmuir 28(16):6714-6723

46. Shao M, Nadeem Zafar M, Sygmund C, Guschin DA, Ludwig R, Peterbauer CK, Schuhmann W, Gorton L (2013) Biosens Bioelectron 40:308-314

47. Tasca F, Harreither W, Ludwig R, Gooding JJ, Gorton L (2011) Anal Chem 83(8):3042-3049
48. Matsumura H, Ortiz R, Ludwig R, Igarashi K, Samejima M, Gorton L (2012) Langmuir 28(29):10925-10933

49. Wang X, Falk M, Ortiz R, Matsumura H, Bobacka J, Ludwig R, Bergelin M, Gorton L, Shleev S (2012) Biosens Bioelectron 31 (1):219-225

50. Coman V, Ludwig R, Harreither W, Haltrich D, Gorton L, Ruzgas T, Shleev S (2010) Fuel Cells 10(1):9-16

51. Falk M, Andoralov V, Blum Z, Sotres J, Suyatin DB, Ruzgas T, Arnebrant T, Shleev S (2012) Biosens Bioelectron 37(1):38-45

52. Feifel SC, Ludwig R, Gorton L, Lisdat F (2012) Langmuir 28:9189-9194

53. Sarauli D, Ludwig R, Haltrich D, Gorton L, Lisdat F (2012) Bioelectrochemistry 87:9-14

54. Cruys-Bagger N, Ren G, Tatsumi H, Baumann MJ, Spodsberg N, Andersen HD, Gorton L, Borch K, Westh P (2012) Biotechnol Bioeng 109:3199-3204

55. Safina G, Ludwig R, Gorton L (2010) Electrochim Acta 55:7690-7695

56. Tasca F, Zafar MN, Harreither W, Nöll G, Ludwig R, Gorton L (2011) Analyst 136(10):2033-2036

57. Zafar MN, Safina G, Ludwig R, Gorton L (2012) Anal Biochem 425(1):36-42

58. Glithero N, Clark C, Gorton L, Schuhmann W, Pasco N (2012) Anal Bioanal Chem (in press)

59. Malel E, Ludwig R, Gorton L, Mandler D (2010) Chem Eur J 16 (38):11697-11706

60. Zamocky M, Ludwig R, Peterbauer C, Hallberg BM, Divne C, Nicholls P, Haltrich D (2006) Curr Prot Pept Sci 7 (3):255-280

61. Zámocký M, Hallberg M, Ludwig R, Divne C, Haltrich D (2004) Gene 338(1):1-14

62. Sygmund C, Kracher D, Scheibelbrandner S, Zahma K, Felice AK, Kittl R, Harreither W, Ludwig R (2012) Appl Environ Microbiol 78(17):6161-6171

63. Phillips CM, Iavarone AT, Marletta MA (2011) J Proteome Res 10(9):4177-4185

64. Sun J, Glass NL (2011) PLoS One 6(9):1-14

65. Sun J, Tian C, Diamond S, Louise Glassa N (2012) Eukaryot Cell 11(4):482-493

66. Tian C, Beeson WT, Iavarone AT, Sun J, Marletta MA, Cate JHD, Glass NL (2009) Proc Natl Acad Sci U S A 106(52):2215722162

67. MacDonald J, Doering M, Canam T, Gong Y, Guttman DS, Campbell MM, Master ER (2011) Appl Environ Microbiol 77 (10):3211-3218

68. Wymelenberg AV, Sabat G, Martinez D, Rajangam AS, Teeri TT, Gaskell J, Kersten PJ, Cullen D (2005) J Biotechnol 118(1):1734

69. Baminger U, Subramaniam SS, Renganathan V, Haltrich D (2001) Appl Environ Microbiol 67(4):1766-1774

70. Harreither W, Sygmund C, Dünhofen E, Vicuña R, Haltrich D, Ludwig R (2009) Appl Environ Microbiol 75(9):2750-2757

71. Cavener DR (1992) J Mol Biol 223(3):811-814

72. Cameron MD, Aust SD (2001) Enzyme Microb Technol 28(23):129-138

73. Henriksson G, Johansson G, Pettersson G (2000) J Biotechnol 78 (2):93-113

74. Coman V, Harreither W, Ludwig R, Haltrich D, Gorton L (2007) Chem Anal (Warsaw) 52(6):945-960

75. Harreither W, Felice AKG, Paukner R, Gorton L, Ludwig R, Sygmund C (2012) Biotechnol J 7:1359-1366

76. Hallberg BM, Henriksson G, Pettersson G, Vasella A, Divne C (2003) J Biol Chem 278(9):7160-7166

77. Li B, Rotsaert FAJ, Gold MH, Renganathan V (2000) Biochem Biophys Res Commun 270(1):141-146 
78. Yoshida M, Ohira T, Igarashi K, Nagasawa H, Aida K, Hallberg BM, Divne C, Nishino T, Samejima M (2001) Biosci Biotechnol Biochem 65(9):2050-2057

79. Langston JA, Brown K, Xu F, Borch K, Garner A, Sweeney MD (2012) Biochim Biophys Acta, Protein Proteom 1824 (6):802-812

80. Xu F, Golightly EJ, Duke KR, Lassen SF, Knusen B, Christensen S, Brown KM, Brown SH, Schülein M (2001) Enzyme Microb Technol 28(9-10):744-753

81. Desriani, Ferri S, Sode K (2010) Biotechnol Lett 32(6):855859

82. Zámocký M, Schümann C, Sygmund C, O’Callaghan J, Dobson ADW, Ludwig R, Haltrich D, Peterbauer CK (2008) Protein Expr Purif 59(2):258-265

83. Larsson T, Elmgren M, Lindquist SE, Tessema M, Gorton L, Henriksson G (1996) Anal Chim Acta 331(3):207-215

84. Maischberger T, Nguyen TH, Sukyai P, Kittl R, Riva S, Ludwig R, Haltrich D (2008) Carbohydr Res 343(12):2140-2147

85. Stoica L, Ludwig R, Haltrich D, Gorton L (2006) Anal Chem 78 (2):393-398

86. Hildén L, Eng L, Johansson G, Lindqvist S-E, Pettersson G (2001) Anal Biochem 290(2):245-250

87. Coman V, Vaz-Dominguez C, Ludwig R, Herreither W, Haltrich D, De Lacey AL, Ruzgas T, Gorton L, Shleev S (2008) Phys Chem Chem Phys 10(40):6093-6096

88. Harreither W, Coman V, Ludwig R, Haltrich D, Gorton L (2007) Electroanalysis 19(2-3):172-180

89. Tasca F, Gorton L, Harreither W, Haltrich D, Ludwig R, Nöll G (2008) J Phys Chem 112(35):13668-13673

90. Tasca F, Gorton L, Harreither W, Haltrich D, Ludwig R, Nöll G (2008) J Phys Chem 112(26):9956-9961

91. Tasca F, Gorton L, Kujawa M, Patel I, Harreither W, Peterbauer CK, Ludwig R, Nöll G (2010) Biosens Bioelectron 25(7):17101716

92. Vasilchenko LG, Karapetyan KN, Yershevich OP, Ludwig R, Zamocky M, Peterbauer CK, Haltrich D, Rabinovich ML (2011) Biotechnol J 6(5):538-553

93. Tasca F, Gorton L, Harreither W, Haltrich D, Ludwig R, Nöll G (2009) Anal Chem 81(7):2791-2798

94. Ortiz R, Matsumura H, Tasca F, Zahma K, Samejima M, Igarashi K, Ludwig R, Gorton L (2012) Anal Chem 84:10315-10323

95. Murata K, Kajiya K, Nukaga M, Suga Y, Watanabe T, Nakamura N, Ohno H (2010) Electroanalysis 22:185-190

96. Fridman V, Wollenberger U, Bogdanovskaya V, Lisdat F, Ruzgas T, Lindgren A, Gorton L, Scheller FW (2000) Biochem Soc Trans 28(2):63-70

97. Dronov R, Kurth DG, Möhwald H, Spricigo R, Leimkühler S, Wollenberger U, Rajagopalan KV, Scheller FW, Lisdat F (2008) J Am Chem Soc 130(4):1122-1123

98. Lisdat F, Dronov R, Möhwald H, Scheller FW, Kurth DG (2009) Chem Commun (3):274-283

99. Spricigo R, Dronov R, Lisdat F, Leimkühler S, Scheller FW, Wollenberger U (2009) Anal Bioanal Chem 393(1):225-233

100. Spricigo R, Dronov R, Rajagopalan KV, Lisdat F, Leimkühler S, Scheller FW, Wollenberger U (2008) Soft Matter 4(5):972978

101. Lindgren A (2000) Electrochemistry of heme containing enzymes - fundamentals and applications. Lund University, Lund, Doctoral dissertation

102. Lindgren A, Gorton L, Ruzgas T, Baminger U, Haltrich D, Schülein M (2001) J Electroanal Chem 496(1-2):76-81

103. Lindgren A, Larsson T, Ruzgas T, Gorton L (2000) J Electroanal Chem 494(2):105-113

104. Stoica L, Dimcheva N, Haltrich D, Ruzgas T, Gorton L (2005) Biosens Bioelectron 20(10):2010-2018

105. Marcus RA (1965) J Chem Phys 43(2):679-701
106. Marcus RA, Sutin N (1985) Biochim Biophys Acta Rev Bioenerg 811(3):265-322

107. Fang J, Huang F, Gao P (1999) Process Biochem 34(9):957-961

108. Larsson T, Lindgren A, Ruzgas T, Lindquist SE, Gorton L (2000) J Electroanal Chem 482(1):1-10

109. Schulz C, Ludwig R, Micheelsen PO, Silow M, Toscano MD, Gorton L (2012) Electrochem Commun 17:71-74

110. Lojou E, Bianco P (2007) Electrochim Acta 52(25):7307-7314

111. Domínguez E, Lan HL, Okamoto Y, Hale PD, Skotheim TA, Gorton L, Hahn-Hägerdal B (1993) Biosens Bioelectron 8(34):229-237

112. Ladiu CI, Popescu IC, Gorton L (2005) J Solid State Electrochem 9(5):296-303

113. Gorton L, Jönsson-Pettersson G, Csöregi E, Johansson K, Domínguez E, Marko-Varga G (1992) Analyst 117(8):12351241

114. Kacaniklic V, Johansson K, Marko-Varga G, Gorton L, JönssonPettersson G, Csöregi E (1994) Electroanalysis 6(5-6):381-390

115. Lutz M, Burestedt E, Emnéus J, Lidén H, Gobhadi S, Gorton L, Marko-Varga G (1995) Anal Chim Acta 305(1-3):8-17

116. Spohn U, Narasaiah D, Gorton L, Pfeiffer D (1996) Anal Chim Acta 319(1-2):79-90

117. Vijayakumar AR, Csöregi E, Heller A, Gorton L (1996) Anal Chim Acta 327(3):223-234

118. Frasca S, Rojas O, Salewski J, Neumann B, Stiba K, Weidinger IM, Tiersch B, Leimkühler S, Koetz J, Wollenberger U (2012) Bioelectrochemistry 87:33-41

119. Stoica L, Ruzgas T, Ludwig R, Haltrich D, Gorton L (2006) Langmuir 22(25):10801-10806

120. Courjean O, Gao F, Mano N (2009) Angew Chem Int Ed Engl 48:5897-5899

121. Demin S, Hall EAH (2009) Bioelectrochemistry 76(1-2):19-27

122. Lindgren A, Tanaka M, Ruzgas T, Gorton L, Gazaryan I, Ishimori K, Morishima I (1999) Electrochem Commun 1 (5):171-175

123. Yakovleva M, Killyeni A, Popescu IO, Ortiz R, Schulz C, MacAodha D, Ó Conghaile P, Leech D, Peterbauer CK, Gorton L (2012) Electrochem Commun 24:120-122

124. Igarashi K, Verhagen M, Samejima M, Schülein M, Eriksson KEL, Nishino T (1999) J Biol Chem 274(6):3338-3344

125. Stoica L, Dimcheva N, Ackermann Y, Karnicka K, Guschin DA, Kulesza PJ, Rogalski J, Haltrich D, Ludwig R, Gorton L, Schuhmann W (2009) Fuel Cells 9(1):53-62

126. Elmgren M, Lindquist SE, Henriksson G (1992) J Electroanal Chem 341(1-2):257-273

127. Gregg BA, Heller A (1991) J Phys Chem 95(15):5970-5975

128. Heller A (1992) J Phys Chem 96(9):3579-3587

129. Heller A (2004) Phys Chem Chem Phys 6(2):209-216

130. Heller A (2006) Curr Opin Chem Biol 10(6):664-672

131. Heller A (2006) Anal Bioanal Chem 385(3):469-473

132. Heller A, Feldman B (2008) Chem Rev 108(7):2482-2505

133. Mano N, Mao F, Heller A (2004) ChemBioChem 5(12):17031705

134. Mano N, Mao F, Heller A (2004) Chem Commun (18):2116 2117

135. Mao F, Mano N, Heller A (2003) J Am Chem Soc 125(16):49514957

136. Pothukuchy A, Mano N, Georgiou G, Heller A (2006) Biosens Bioelectron 22(5):678-684

137. Guschin DA, Castillo J, Dimcheva N, Schuhmann W (2010) Anal Bioanal Chem 398(4):1661-1673

138. Yakovleva M, Buzas O, Matsumura H, Samejima M, Igarashi K, Larsson P-O, Gorton L, Danielsson B (2012) Biosens Bioelectron 31(1):251-256

139. Bao W, Usha SN, Renganathan V (1993) Arch Biochem Biophys 300(2):705-713 
140. Habu N, Igarashi K, Samejima M, Pettersson B, Eriksson K-EL (1997) Biotechnol Appl Biochem 26(2):97-102

141. Temp U, Eggert C (1999) Appl Environ Microbiol 65(2):389_ 395

142. Ludwig R, Haltrich D (2003) Appl Microbiol Biotechnol 61 (1):32-39

143. Roy BP, Dumonceaux T, Koukoulas AA, Archibald FS (1996) Appl Environ Microbiol 62(12):4417-4427

144. Canevascini G, Borer P, Dreyer J-L (1991) Eur J Biochem 198(1):43-52

145. Subramaniam SS, Nagalla SR, Renganathan V (1999) Arch Biochem Biophys 365(2):223-230

146. Vasil'chenko LG, Khromonygina VV, Karapetyan KN, Vasilenko OV, Rabinovich ML (2005) J Biotechnol 119(1):44-59
147. Bey M, Berrin JG, Poidevin L, Sigoillot JC (2011) Microb Cell Fact 10:113

148. Stapleton PC, O'Brien MM, O'Callaghan J, Dobson ADW (2004) Enzyme Microb Technol 34(1):55-63

149. Trashin SA, Haltrich D, Ludwig R, Gorton L, Karyakin AA (2009) Bioelectrochemistry 76(1-2):87-92

150. Tessema M, Larsson T, Buttler T, Csöregi E, Ruzgas T, Nordling M, Lindquist SE, Pettersson G, Gorton L (1997) Anal Chim Acta 349(1-3):179-188

151. Fujita K, Nakamura N, Igarashi K, Samejima M, Ohno H (2009) Green Chem 11:351-354

152. Fujita K, Nakamura N, Murata K, Igarashi K, Samejima M, Ohno H (2011) Electrochim Acta 56:7224-7227 